\title{
Türkiye İşgücü Piyasasında Bireylerin Aşırı Eğitimliliğinin Ölçülmesi: İki Değişkenli Probit Model Uygulaması
}

\author{
Selena KANTARMACI (https://orcid.org/0000-0002-0809-9477), Department of Econometrics, Dokuz. Eylül \\ University, Turkey; e-mail: selenakantarmaci@gmail.com
}

Sercan DEMIROGLARI (https://orcid.org/0000-0002-0091-9223), Department of Econometrics, Dokuz, Eylül University, Turkey; e-mail: sercan.demiroglari@deu.edu.tr

Hande ERK (https://orcid.org/0000-0003-3569-042X), Department of Econometrics, Dokuz. Eylül University, Turkey; e-mail: handeerk1@gmail.com

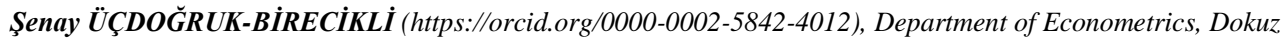
Eylül University, Turkey; e-mail: s.ucdogruk@deu.edu.tr

\section{Measurement of Individuals' Overeducation in the Labour Market of Turkey: Bivariate Probit Model Application}

\begin{abstract}
The present study aims to empirically investigate the overeducation phenomenon within the context of the Turkish labour market. For this purpose, data belonging to the working population aged 15-65 are extracted from the Turkish household workforce survey results covering the period of 20142018. Analyses were conducted based on a two-state probit model. Heckman's (1979) two-stage probit selection model was used to consider unobservable factors affecting the decision to participate in the labour market and the overeducation status. The findings indicate that while experience harms overeducation, an increase in the education level has a positive effect on overeducation. The study concludes with policy recommendations.
\end{abstract}

Keywords $\quad$ : Overeducation, Probit Model, Heckman's Two-Stage Selection Model.

JEL Classification Codes : $\quad$ C25, I2.

\section{Öz}

Çalışmanın amacı işgücü ile aşırı eğitim arasındaki ilişkiyi ortaya koyarak Türkiye için bir uygulama sunmaktır. Bu kapsamda 2014-2018 yılları hanehalkı işgücü verilerinden yararlanılarak 1565 yaşlarında SGK'ya kayıtlı istihdamdaki bireylerle çalışılmıştır. Ekonometrik modellemede iki durumlu probit modelin yanısıra hem işgücü piyasasına katılma kararını hem de aşırı eğitimlilik durumunu etkileyen gözlemlenemeyen faktörleri hesaba katmak amaciyla Heckman'ın (1979) iki aşamalı probit seçim modeli kullanılmıştır. Elde edilen bulgular deneyimin aşırı eğitim üzerinde negatif bir etkiye sahip olduğu yönündedir. Bireyin eğitim düzeyinde meydana gelecek bir artış ise aşırı eğitim üzerinde pozitif bir etki yaratmaktadır. Çalışmada ayrıca politika değerlendirmelerinde bulunulmuştur.

\section{Anahtar Sözcükler $\quad$ : Aşırı Eğitimlilik, Probit Model, İki Aşamalı Heckman Probit Seçim Modeli.}


Kantarmacı, S. \& S. Demirogları \& H. Erk \& Ş. Üçdoğruk-Birecikli (2021), "Türkiye İşgücü Piyasasında Bireylerin Aşırı Eğitimliliğinin Ölçülmesi: İki Değişkenli Probit Model Uygulaması”, Sosyoekonomi, 29(48), 271-292.

\section{Giriş}

Genel anlamda insan sermayesi, bireyin doğuştan kazandığı ve sonradan geliştirdiği özelliklerin değerini göstermektedir. İnsanın üretim sürecindeki yerini sahip olduğu yetenekler ve özellikler belirlemektedir. Ayrıca gelir yaratıcı ekonomik faaliyetlere katkı sağlayan bireydeki bilgi, beceri ve benzer nitelikler olarak da tanımlanan beşerî sermaye, insana yapılan yatırımlarla artmakta ve üretim sürecinin vazgeçilmez bir girdisi olmaktadır (Çakmak \& Gümüş, 2005: 60). Makro düzeyde bir ülkenin kalkınmasında, mikro düzeyde birey ve firmaların gelişiminde önemli bir yere sahip olan eğitim, sağlamış olduğu bireysel ve toplumsal faydalarla vazgeçilemez bir yatırım aracıdır. Eğitime yapılan yatırım, bireyin beşerî sermayesine yapılan yatırımdır. Beşerî sermaye kazanımı ile bireyin verimliliğinde artışlar meydana gelmektedir. Verimlilikteki bu artış, daha yüksek eğitim seviyesi beklentisi sonucunu doğurmaktadır. Dolayısıyla yüksek eğitim seviyesinde olanların işsizlik sorunuyla karşı karşıya kalması daha düşük bir ihtimaldir (Saxton, 2000: 3).

Türkiye İstatistik Kurumuna ait eğitim harcamaları istatistikleri incelendiğinde devlet ve hanehalkları tarafından gerçekleştirilen toplam eğitim harcamalarının 2011 yılından 2018 yılına kadar yaklaşık üç kat artış gösterdiği görülmektedir (TÜİK, 2019). Türkiye'de 15-64 yaş arasındaki eğitim durumuna göre istihdam oranı istatistikleri bunu destekler ve doğrular niteliktedir (TÜİK, 2020). Eğitimin istihdam üzerindeki etkileri olumlu olsa da Türkiye için genel ve genç işsizlik oranları 2014 yılından bu yana bir artış trendine sahiptir. Ülkemizde 2018-2019 eğitim öğretim yılı itibariyle yükseköğretim kurumlarında kayıtlı öğrenci sayısı 7740502 'dir. Bununla birlikte 2020 yılı Mayıs ayı itibariyle ülkedeki akademisyen sayısı ise 175409'dur (YÖK, 2020). 1980 yılından itibaren üniversitelere başvurup yerleşenlerin sayısı \%8,9'lardan \%36 seviyelerine kadar yükselmiştir. Üniversitelere yerleşenlerin ve mezunların sayıları artırmıştır. Ancak eğitim sisteminin bu kadar hızla büyüyor olması beraberinde başka sorunları da getirmektedir. Mezun sayılarının artmış olması, işgücü piyasasına emeğini arz etmeye hazır olan genç bireylerin varlığı, piyasanın artan arz karşısında talebi yeterince karşılayamaması, yeni iş imkânlarının yaratılamaması gibi sorunlar Türkiye'de aşırı eğitimlilik kavramının ortaya çıkmasına zemin hazırlamaktadır. Ekonomik kriz dönemlerinde bireylerin uzun süre işsiz kalma kaygısı ve işverenlerin mevcut işleri yürütmek için açık pozisyonları değerlendirmesiyle uyumsuz eşleşmeler ortaya çıkmaktadır (Kurnaz, 2015: 47). Uyumsuz eşleşme kavramı, istihdamda yer alan bireyin iki tür uyumsuzlukla karşı karşıya kaldığını vurgulamaktadır (ILO,2018). Bunlar sırasıyla nitelik uyumsuzluğu (qualification mismatch) ve beceri uyumsuzluğudur (skill mismatch). Nitelik uyumsuzluğu, çalışanların sahip olduğu yeterlilikler ile işlerin gerektirdiği nitelikler arasındaki tutarsızlığı vurgulamaktadır. Eğitimsel uyumsuzluk (educational mismatch) olarak da bilinen bu kavram, istihdamda olan kişinin eğitim seviyesinin, yapmakta olduğu iş için gerekli olan eğitim seviyesiyle uyuşmadığında ortaya çıkmaktadır. Bu durumda aşırı eğitim ya da eksik eğitim kavramları söz konusu olmaktadır.

Aşırı eğitim terimi, çalışanın eğitim seviyesinin, o iş için gerekli eğitim seviyesini aştığı bir iş uyumsuzluğunu ifade etmektedir (Rossen vd., 2019: 2). Aşırı eğitimli çalışanlar, mevcut işleri ile ilgili görevleri yerine getirmek için olduğundan daha fazla bilgi, beceri veya yeterliliklerle donatılmışlardır. Tam tersine çalışanın eğitim seviyesi, işin gerektirdiği 
Kantarmacı, S. \& S. Demirogları \& H. Erk \& Ş. Üçdoğruk-Birecikli (2021), "Türkiye İşgücü Piyasasında Bireylerin Aşırı Eğitimliliğinin Ölçülmesi: İki Değişkenli Probit Model Uygulaması”, Sosyoekonomi, 29(48), 271-292.

ortalama eğitim seviyesinden daha az ise eksik eğitim durumu söz konusu olmaktadır. Özellikle, aşırı eğitim, olumsuz sonuçları sebebiyle eksik eğitimden daha fazla ilgi görmektedir (Chia-Yu Hung, 2008: 127). Literatür incelendiğinde bazı araştırmalarda söz konusu kavramın farklı şekillerde sınıflandırıldığı görülmektedir. Örneğin Chevalier (2003: 509-31), aşırı eğitimi çalışanların iş tatmin düzeyini dikkate alarak görünürde aşırı eğitimli (apparently overeducated) ve gerçekte aşırı eğitimli (genuinely overeducated) olarak sınıflandırmıştır. Green ve Zhu (2010: 740-763) ise çalışmalarında becerilerin kullanımına ilişkin gerçek aşırı eğitim (real overeducation), formel aşırı eğitim (formal overeducation) sınıflaması yapmışlardır. Aşırı eğitim terimini, ilk olarak Freeman (1976) "The Overeducated American" adlı kitabında, savaş sonrası Amerikan nüfusundaki yükseköğretimin yaygınlaşması sonucu ifade etmiştir. Freeman, kitabında mezun sayılarındaki fazlalık sebebiyle eğitimin getiri oranındaki olası düşüşlere karşı uyarılarda bulunmuştur (Dolton \& Vignoles, 2000: 180). Bu süreçten sonra aşırı eğitim kavramı, birçok araştırmaya konu olmuştur. Özellikle araştırmalar, kendi eğitim seviyesinden daha düşük işlerde çalışan aşırı eğitimli bireylerin daha az kazandıklarını, ancak gerçekte gerekli olan eğitim seviyesindeki benzer işlerde çalş̧an bireylerden de daha fazla kazandıklarını göstermektedir (Duncan \& Hoffman, 1981: 75-86; Van Smoorenburg \& Van der Velden, 2000: 207-17). Aşırı eğitimin olumsuz yönlerinden bir diğeri de örgün eğitimde elde edilen yetenekleri veya becerileri değersizleştirmesidir. Çünkü çalışan söz konusu bireyler, aşırı eğitimin içerisinde oldukları sürede yetenek ve becerilerini geliştiremeyecektir (De Grip vd., 2008: 2-4). Bir başka bakış açısı da aşırı eğitim ile iş tatmini arasındaki ilişkidir. Aşırı eğitimli çalışanların benzer işlerde çalışıp yeterli eğitim düzeyine sahip olanlardan daha az iş tatmin düzeyinin olduğu görüşünü savunan bulunmaktadır (Hersch, 1991: 140-44; Verhaest \& Omey, 2009: 469-81). Oysa böyle bir ilişkinin olmadığ sonucuna ulaşan araştırmacilar da mevcuttur (Büchel, 2002: 263-75; Verhaest \& Omey, 2006: 419-48).

Türkiye'de ise aşırı eğitimlilik ile ilgili yapılan çalışmaların oldukça sınırlı olduğu görülmektedir. Filiztekin (2015: 201-14), TÜİK Hanehalkı İşgücü Anketi 1994 ve 2002 yılları verileriyle gerçekleştirdiği çalışmasında aşırı eğitimin ve eksik eğitimin belirleyicilerini birtakım demografik değişkenler bazında araştırmıştır. Daha detaya inerek aşırı ve eksik eğitimin ücretler üzerine etkisini irdelemiş ve araştırma yapılan her iki yılda da aşırı eğitimlilerin daha yüksek ücret aldığını göstermiştir. Buna karşın Acar (2017: 33954), Filiztekin'den farklı olarak panel veride aynı bireyleri gözlemlemiştir. 2006-2010 yılları arasındaki TÜİK Gelir ve Yaşam Koşulları anketi verilerinden yararlanarak gerçekleştirmiş olduğu çalışmasında, aşırı ya da eksik eğitimin ücretler üzerinde anlamlı bir etkisinin olmadığını tespit etmiştir. Bulguları ise Filiztekin'den farklıdır. Gönültaş (2019: 223-41), Türkiye İş Kurumu'na ait 2016 yılı verileriyle sadece Ankara'da yaşamakta olan 15-29 yaş arasında yer alan ve Ankara'da bulunan üniversitelerden mezun olan 1234 kişiyle uyumsuz eşleşme kavramını irdelemiş ve İŞKUR aracılığıyla işe yerleştirilen 15-29 yaş arasındaki bireyler arasında aşırı eğitimliliğin Ankara özelinde \%67 dolaylarında olduğunu tespit etmiştir. Yukarıdaki çalışmalardan farkı bölgesel verilerle çalışmasıdır. Kurnaz (2014: 308), TÜİK Hanehalkı İşgücü 2014 verilerinden yararlanarak Uluslararası Meslek Sınıflaması (ISCO 08) ile Uluslararası Standart Eğitim Sınıflaması (ISCED) arasındaki ilişkiden yararlanarak Türkiye'de istihdamda olan 15-24 yaş arasındakilerin \%57,5, 15-64 yaş 
arasındakilerin ise \%33,9 oranında aşırı eğitimli olduğunu gözlemlemiştir. Bölgesel bir çalışma olduğu için diğer çalışmalarla karşılaştırılmamaktadır.

Çalışmanın bundan sonraki kısmında öncelikle aşırı eğitimin ölçülmesi ve Türkiye'de istihdamın mesleki yapısı hakkında bilgi verilecektir. Ardından ekonometrik modellemeye ilişkin teorik çerçeveye kısaca değinilip probit ve iki değişkenli (bivariate) probit modelin yapısı aşırı eğitimlilik kapsamında açıklanacaktır. Üçüncü bölümde kullanılan veri yapısı ve tanımlayıcı istatistikler hakkında bilgi verildikten sonra tahminlenen model sonuçları yorumlanacaktır. Çalışmanın sonunda ise tartışma ve sonuç k1smina yer verilecektir.

\section{Aşırı Eğitim ve İstihdam Yapısı}

\subsection{Aşırı Eğitimin Ölçülmesi}

Aşırı eğitimle ilgili literatürde temel konulardan biri gerekli eğitim miktarının nasıl ölçüleceğidir. Aşırı eğitimin ölçümü ile ilgili olarak en çok kullanılan yöntemler üç grupta toplanabilir: iş analizi, gerçekleşen eşleşmeler ve öz irade beyanı. İş analizi ve gerçekleşen eşleşmeler nesnel, öz irade beyanı ise öznel yöntem olarak bilinmektedir (CapsadaMunsech, 2019: 281).

Şekil: 1

\section{Aşırı Eğitim Ölçüm Yöntemleri}

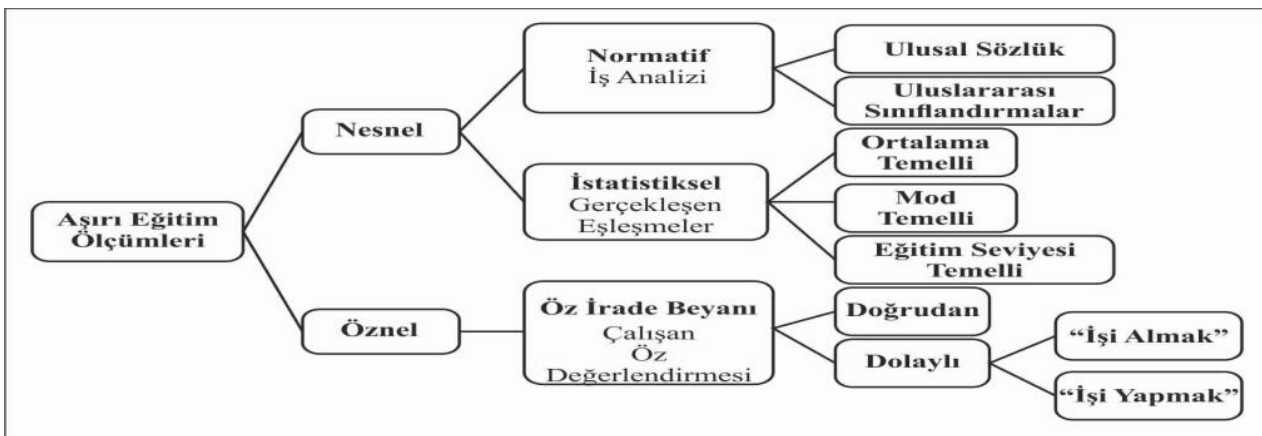

Kaynak: Capsada-Munsech, 2019.

1) Çalışan öz değerlendirmesi: Aşırı eğitimi ölçmede kullanılan yöntem ilk olarak Duncan \& Hoffman (1981: 75-86) tarafından önerilmiş olup öznel bir ölçüm yöntemi esasına dayanmaktadır. Öz değerlendirme yöntemi, çalışanlara işlerinin gereksinimleri hakkında sorulan sorulara dayanmaktadır (Nieto, 2014: 10). Bireyin kendisi hakkında değerlendirmelerde bulunduğu bir yaklaşımla aşırı eğitimi ölçmek, bireyin iş gereksinimi için gerekli olan eğitim düzeyi ve/veya becerileriyle eşleşip eşleşmediği hakkındaki görüşlerini kullanmaktan ibarettir. Bu yöntemi doğrudan ve dolaylı öz değerlendirme yöntemi olarak sınıflandırmak mümkündür. Doğrudan öz değerlendirmede, çalışanlara aşırı eğitimli olup olmadıkları hakkındaki düşünceleri sorulmaktadır. Dolaylı öz değerlendirme yönteminde ise yapmakta oldukları iş için gerekli olan eğitim seviyesi sorulmaktadır. 
Çalışanların cevapları ile mevcut işlerindeki eğitim düzeyleri karşılaştırılarak aşırı eğitimli olup olmadıkları belirlenmektedir (Verhaest \& Omey, 2006: 421). Diğer ölçümlerle karşılaştırıldığında, öznel yaklaşımda bilgi, mevcut iş durumuna en yakın kaynaktan sağlanmaktadır (Hartog \& Oosterbeek, 1988: 186). Fakat öznel yöntemlere getirilen eleştiriler de vardır. İlk olarak, aşırı eğitimli çalışanların, işlerindeki ilgisizlik sebebiyle anketlere cevap verme olasılığı az olmaktadır. İkinci olarak, daha küçük ölçekli kuruluşlardaki çalışanlar, iş gereksinimleri değerlendirmek için yeterli ölçütlerden yoksun olabilirler. $\mathrm{Bu}$ da ölçüm hatasına yol açmaktadır. Son olarak katılımcıların iş gereksinimlerini değerlendirirken farklı değerlendirmelerde bulunma ihtimalleri söz konusu olabilmektedir (McGuinnes, 2006: 396). OECD’nin önderliğindeki “Uluslararası Yetişkin Becerilerinin Ölçülmesi Programı” (PIAAC), 16-65 yaş arasındaki bireylerin temel becerilerini ölçmesinin yanı sıra aynı zamanda nitelik uyumsuzluklarını da değerlendirmektedir. Söz konusu araştırmada çalışanlara, şu anda çalışmakta oldukları işe bir başkası başvurmak istediğinde hangi niteliklere sahip olması gerektiği ile ilgili sorular sorulmaktadır. Araştırmadan elde edilen sonuçlara göre OECD ülkelerindeki ortalama aşırı niteliklilik ortalama \%22 seviyelerinde iken, yetersiz nitelikliliğin $\% 12$ dolayında olduğu ifade edilmektedir. Aynı araştırmanın sonuçları Türkiye açısından irdelendiğinde ise aşırı niteliklilerin oranı \%12 iken yetersiz niteliklilerin oranı da yaklaşık olarak \%13 civarlarındadır (OECD, 2019).

2) İş analizi: Yöntem, eğitim ve meslekler arasında, mesleklerin eğitim gereksinimlerini değerlendiren iş uzmanlarının ölçütleri üzerine kurulmuştur (Verhaest \& Omey, 2006: 422). İş uzmanlarının sınıflandırmasına göre, bir çalışanın, eğitim seviyesi işi yapmak için gerekli seviyeyi aştığında onun aşırı eğitildiği düşünülmektedir. Bu nesnel ölçüm, her iş için doğru eğitim türünün ve düzeyinin açık tanımlarına dayanmaktadır. Aynı tanımlar ve gereksinimler, tüm meslek türlerinde kullanılır ve meslek unvanları sözlüklerinin oluşturulmasına olanak sağlar (Ortiz \& Kucel, 2008: 311). Kavramsal olarak, sistematik iş analizi, açık nesnel hedefi, tanımları ve ayrıntılı ölçüm talimatları nedeniyle iş gereksinimlerini tanımlamak için çekici bir kaynaktır (Hartog, 2000: 132). Fakat bu yöntemdeki temel sorunlardan birisi meslek sözlükleri sınıflandırılması zorluğudur. Söz konusu sınıflandırmalar genellikle yapılmamaktadır, yapılsa bile teknolojik değişime hassas oldukları için hızla değişime uğrayıp güncelliğini yitirmektedir (Ramos, 2014: 3).

3) İstatistiksel Yöntem: Bir diğer nesnel yaklaşımda öne çıkan istatistiksel yöntem gerçekleşen eşleşme durumuna dayanmakta ve eldeki veriler üzerinden bir sınıflandırma yapılmaktadır. Gerçekleşen eşleşmeler, belirli bir meslekte çalışanların gözlemine ve edinilen eğitim düzeylerinin ölçülmesine dayanmaktadır. "Eşleşmiş" grubu ortaya çıkarmak için çeşitli merkezi eğilim ölçümleri hesaplanmakta, aritmetik ortalama, mod veya 80. yüzdelik üzerinden hesaplama yapılmaktadır. Aritmetik ortalamayı temel alan istatistiksel yöntemde bir meslek grubu içindeki ortalama eğitim seviyesinden, bir standart sapma yukarıdaki ya da aşağıdaki eğitim seviyesindekiler, sırasıyla aşırı ve eksik eğitimli olarak gruplandırılmaktadır (Verdugo \& Verdugo, 1989: 629-43). Bir diğer yaklaşımda bir meslek grubunda gözlemlenen eğitim düzeylerinin dağılımı belirli bir yüzdelik dilimi aşanların, aşırı eğitimli olduğu düşünülmektedir. Ortiz ve Kucel, (2008:312) çalışmasında çeşitli yüzdeleri de test etmiş ve kullandıkları veri için 80 . ile 70. yüzdelik arasında önemli bir fark olmadığını 
ileri sürmüştür. Rossen vd. (2019: 9) 80. yüzdeliğin oldukça “yüksek” bir eşik değer olduğunu belirtmektedir. Kiker vd. (1997: 111-25), De Oliveria vd. (2000: 199-206), Bauer (2002: 221-29), Lin \& Wang (2005: 31-48) ise verilerdeki sapan değerlerin varlığına daha az duyarlı olduğundan aritmetik ortalama yerine modu kullanmışlardır. Bir işte gerekli eğitim seviyesini, bu işte çalışan bireylerin tamamlanmış eğitim seviyelerinin modu olarak tanımlamışlardır. Bu seviyeden daha fazla eğitimli olanları aşırı ve daha az olanları eksik eğitimli olarak nitelendirmişlerdir.

Çalışmamızda hanehalkı işgücü verileriyle çalışıldığından aşırı eğitimin ölçümlenmesinde Ortiz \& Kucel (2008), De oliveria vd. (2000) ve Verdugo \& Verdugo (1989)'nun çalışmaları referans alınmış ve üç istatistiksel yöntem kullanılarak sonuçlar raporlanmıştır. Literatürde yazarlar mod ölçümü üzerinden modelin daha tutarlı olduğunu belirtmektedirler. Bu çalışmada elde edilen ölçümlerin yorumlanmasında yukarıdaki literatür takip edilerek mod ile hesaplanmış model yorumlamaları verilmiştir.

\subsection{Türkiye'de İstihdamın Mesleki Yapısı}

Aşırı eğitimlilik boyutunun incelenmesinde daha çok ILO tarafından kullanılmış olan ISCO 08 (Uluslararası Standart Meslek) ve ISCED 97 (Uluslararası Standart Eğitim) sınıflamalarına dayanan nesnel ölçüm yöntemi kullanılmaktadır. Uluslararası Meslek Sınıflaması (ISCO 08), bir işi yapmak için gerekli olan nitelik, beceri ve uzmanlık düzeyini dikkate almakta ve işleri bu unsurlara göre mesleki kategorilere ayırmakta dolayısıyla ana meslek kategorileri ile bu kategorilere uygun nitelik düzeyleri arasında ilişki kurulmasını sağlamaktadır. TÜİK tarafından 2013 yılından sonra ISCO 08'in kullanımına geçilmiştir. Uluslararası Standart Eğitim Sınıflandırması olan ISCED, nitelik ve eğitim düzeyleri arasındaki ilişkiyi tanımlamaktadır. Meslek sınıflaması (ISCO 08), Çalışan hanehalkı fertlerinin yaptıkları işle ilgili meslek gruplarının kodlanması için aşağıdaki Tablo 1 kullanılmaktadır.

Tablo: 1

\section{ISCO 08 Meslek Sinıflandırması}

\begin{tabular}{|l|l|}
\hline 1. & Yöneticiler \\
\hline 2. & Profesyonel meslek mensupları \\
\hline 3. & Teknisyenler, teknikerler ve yardımcı profesyonel meslek mensupları \\
\hline 4. & Büro hizmetlerinde çalşan elemanlar \\
\hline 5. & Hizmet ve satış elemanları \\
\hline 6. & Nitelikli tarı, ormancılık ve su ürünlerinde çalışanlar \\
\hline 7. & Sanatkârlar ve ilgili işlerde çalışanlar \\
\hline 8. & Tesis ve makine operatörleri ve montajcıları \\
\hline 9. & Nitelik gerektirmeyen işlerde çalışanlar \\
\hline
\end{tabular}

Kaynak: ISCO 08, ILO.

Tablo 2'de Eğitim Durumu Sınıflaması (ISCED 1997) görülmektedir. 15 ve yukarı yaştaki fertlerin eğitim durumları hakkındaki bilgiler Uluslararası Standart Eğitim Siniflamasina (ISCED, 1997)'ye, (International Standard Classification of Education, ISCED) uygun olarak oluşturulmuştur. 
Tablo: 2

ISCED Eğitim Durumu Sınıflandırması

\begin{tabular}{|l|l|}
\hline 0 & Okul bitirmemiş \\
\hline 1 & İlkokul (5 yıllık) \\
\hline 2 & Genel orta, mesleki, teknik ortaokul (8 yıllık) \\
\hline 3 & Genel lise \\
\hline 4 & Meslek lisesi/teknik lise \\
\hline 5 & 2,3 veya 4 yıllık Y.O., Fakülte \\
\hline 6 & Yüksek Lisans (5 veya 6 yıllık Fakülte) veya Doktora \\
\hline
\end{tabular}

Kaynak: TÜIK, ISCED 1997.

Yukarıdaki Tablo 1 ve 2'den yola çıkarak Türkiye'de işgücü piyasasında istihdamda olan ve SGK'ya kayıtlı 2014-2018 yılları arasındaki bireylerin eğitim seviyelerinin dağılımı Tablo 3'te oluşturulmuştur. Beşerî sermayenin en önemli unsurlarından biri olan eğitimin, Türkiye için ne kadar kritik seviyelerde olduğu Tablo 3'te göze çarpmaktadır. İstihdamda olanların yaklaşık olarak \%26'sı ilkokul mezunu iken, genel lise ve meslek liselerinde olanların dağılımı sırasıyla \%24 ve 26'dır. Yüksekokul, fakülte mezunu olanlardan yalnızca \%3’ü istihdamda iken, yüksek lisans veya doktora mezunları \%1 civarındadır.

Tablo: 3

Türkiye’de 2014-2018 yıllarında Hanehalkı İşgücü Anketine Göre Çalışanların Eğitim Seviyelerinin Dağılımları

\begin{tabular}{|l|c|}
\hline Eğitim Seviyesi & Yüzde \\
\hline Okul bitirmemiş & 1,63 \\
\hline Illkokul (5 yillı) & 5.097 \\
\hline Genel orta, mesleki, teknik ortaokul (8 y1llık) & 82.629 \\
\hline Genel lise & 55.297 \\
\hline Meslek lisesi/teknik lise & 17,67 \\
\hline 2, 3 veya 4 yillık Y.O., Fakülte & 24,16 \\
\hline Yüksek Lisans (5 veya 6 yillık Fakülte) veya Doktora & 25,79 \\
\hline Toplam & 2,90 \\
\hline
\end{tabular}

Araştırmaya konu olan yıllardaki meslek gruplarının yıllara göre dağılımı da Tablo 4'te frekans bazında ve uyumsuz eşleşmeye göre dağılımı ise Şekil 2'de yüzde olarak verilmektedir. Tablo 4 incelendiğinde istihdamda olup SGK'ya kayıtlı toplam 312954 kişi bulunmaktadır. Kayıtlı istihdamın en yüksek kısmını \% 19,62 ile "hizmet ve satış elemanları" oluşturmaktadır. Bu da piyasada gerçekleştirilecek hizmetin yerine getirilmesi için söz konusu grupta olan çalışanların fazla olması gerektiği bilgisi ile uyumludur. Hizmet ve satış elemanları meslek grubunu takiben sırasıyla "sanatkârlar ve ilgili işlerde çalışanlar", "profesyonel meslek grupları gelmektedir. Belirtilen yıllarda kayıtlı istihdamın en az kısmını oluşturan meslek grupları ise sırasıyla "nitelikli tarım, ormancılık ve su ürünlerinde çalışanlar", "yöneticiler" ve "teknisyenler, teknikerler ve yardımcı profesyonel meslek grupları"dır. Şekil 2'de en yüksek eksik eğitim yüzdesine sahip meslek grubu \%30,44 ile büro hizmetlerinde çalışan elemanlar iken, en yüksek yeterli eğitim yüzdesine $\% 21,07$ ile hizmet ve satış elemanları ve en yüksek aşırı eğitim yüzdesine $\% 28,24$ ile sanatkârlar ve ilgili işlerde çalışanlar sahiptir. 
Tablo: 4

Türkiye'de 2014-2018 yıllarında Hanehalkı İşgücü Anketine Göre Meslek Gruplarının Yıllara Göre Yüzdesel Dağılımı (2014-2018)

\begin{tabular}{|c|c|c|c|c|c|c|}
\hline Meslek Grupları (ISCO) & 2014 & 2015 & 2016 & 2017 & 2018 & Toplam \\
\hline Yöneticiler & 6,43 & 6,49 & 6,44 & 6,40 & 6,20 & 6,44 \\
\hline Profesyonel Meslek Mensupları & 13,37 & 13,22 & 14,06 & 14,81 & 14,62 & 13,67 \\
\hline Teknisyenler, Teknikerler ve Yardımcı Profesyonel Meslek Grupları & 7,24 & 7,32 & 7,29 & 7,82 & 7,46 & 7,32 \\
\hline Büro Hizmetlerinde Çalışan Elemanlar & 9,34 & 9,37 & 9,49 & 9,85 & 9,79 & 9,44 \\
\hline Hizmet ve Satış Elemanları & 19,32 & 19,87 & 19,61 & 19,75 & 19,88 & 19,62 \\
\hline Nitelikli Tarım, Ormancılık ve Su Ürünlerinde Çalışanlar & 6,04 & 5,88 & 5,35 & 4,81 & 4,40 & 5,64 \\
\hline Sanatkârlar ve İlgili İşlerde Çalışanlar & 15,26 & 14,63 & 14,30 & 14,01 & 14,76 & 14,70 \\
\hline Tesis ve Makine Operatörleri ve Montajcıları & 11,26 & 11,03 & 11,18 & 11,55 & 11,33 & 11,18 \\
\hline Nitelik Gerektirmeyen İşlerde Çalışanlar & 11,74 & 12,21 & 12,27 & 11,01 & 11,55 & 11,99 \\
\hline Toplam & 29,73 & 30,19 & 29,70 & 5,03 & $\mathbf{5 , 3 5}$ & 100,00 \\
\hline
\end{tabular}

Şekil: 2

Meslek Gruplarının Moda Göre Yüzdesel Uyumsuz Eşleşme Dağılımları

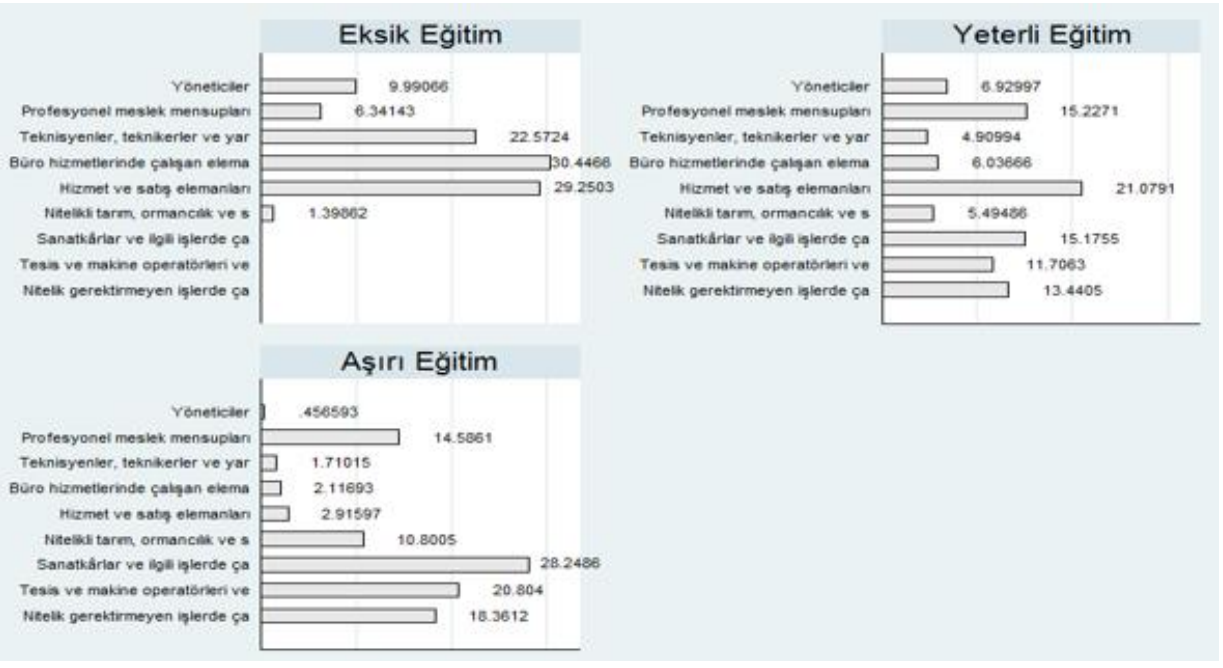

Tablo: 5

Türkiye'de 2014-2018 yıllarında Hanehalkı İşgücü Anketine Göre Aşırı Eğitimliliğin 80. Yüzdelik, Mod ve Ortalama Ölçümlerinin Yüzdesel İstatistiksel Dağılımı

\begin{tabular}{|c|c|c|c|c|c|c|}
\hline \multicolumn{7}{|l|}{ 80. Yüzdelik } \\
\hline & 2014 & 2015 & 2016 & 2017 & 2018 & Toplam \\
\hline Aşırı Eğitimli & 7,84 & 8,67 & 9,31 & 9,93 & 34,68 & 10,07 \\
\hline Aşırı Eğitimli Olmayan & 92,16 & 91,33 & 90,69 & 90,07 & 65,32 & 89,93 \\
\hline Toplam & 100,00 & 100,00 & 100,00 & 100,00 & 100,00 & 100,00 \\
\hline \multicolumn{7}{|l|}{ Mod } \\
\hline & 2014 & 2015 & 2016 & 2017 & 2018 & Toplam \\
\hline Așırı Eğitimli & 14,19 & 14,50 & 14,86 & 14,58 & 30,88 & 15,40 \\
\hline Aşırı Eğitimli Olmayan & 85,81 & 85,50 & 85,14 & 85,42 & 69,12 & 84,60 \\
\hline Toplam & 100,00 & 100,00 & 100,00 & 100,00 & 100,00 & 100,00 \\
\hline \multicolumn{7}{|l|}{ Ortalama } \\
\hline & 2014 & 2015 & 2016 & 2017 & 2018 & Toplam \\
\hline Aşırı Eğitimli & 12,96 & 13,80 & 14,66 & 15,07 & 34,68 & 10,07 \\
\hline Aşırı Eğitimli Olmayan & 87,04 & 86,20 & 85,34 & 84,93 & 65,32 & 89,93 \\
\hline Toplam & 100,00 & 100,00 & 100,00 & 100,00 & 100,00 & 100,00 \\
\hline
\end{tabular}

Not: 80. yüzdelik için mod ve ortalama yazarlar tarafindan hesaplanmıştır. 
Çalışmada, 2014-2018 yılları arasında istihdamda olup SGK' ya kayıtlı olan bireylerin aşırı veya eksik eğitimin ölçülmesinde istatistiksel yöntemlerden yararlanılmıştır. Tablo 5'te aşırı eğitimliliğin 80 . yüzdelik, mod ve ortalama ölçümlerinin istatistiksel dağılımı görülmektedir.

2014-2018 yılları arasında 312954 bireyin yer aldığı veri setinde 80. yüzdelikte, $\% 10,07$, modda $\% 15,40$ ve ortalamaya göre yapılan hesaplamada ise $\% 10,07$ oranında aşırı eğitimli birey tespit edilmiştir. Türkiye'de aşırı eğitimin ölçümü ile ilgili literatür incelendiğinde daha çok ortalama ve modun esas alındığı görülmüştür. Filiztekin (2015), moda göre yapmış olduğu hesaplamasında 1994 yılında toplam nüfusun \%20'sinin; 2002 yılında ise \%25'inin aşırı eğitimli olduğunu tespit etmiştir. Acar (2016) ise aşırı eğitimin ölçümünü ortalama ve mod temelinde gerçekleştirmiş, ortalamaya göre yapılan hesaplamada gözlemlerin \%22,49'unun, moda göre yapılan hesaplamada ise \%29,82'sinin aşırı eğitimli olduğunu hesaplamıştır. Çalışmamızda ayrıca, 80. yüzdelik üzerinden de aşırı eğitim ölçülmüştür. Tablo 5'te üç ölçümün durum saptaması görülmektedir. Tablo 6'da 2014-2018 yılları arasında istihdamda olan ve SGK' ya kayıtlı olanların 80. yüzdelik, mod ve ortalamaya göre istatistiksel dağılımları görülmektedir. 80. yüzdeliğe göre yapılan hesaplamalara göre istihdamda olan ve SGK'ya kayıtlı olanların \%10'u aşırı eğitimli, yaklaşık \%48'i eksik eğitimli, \%42'si de yeterli eğitimlidir. Moda göre yapılan hesaplamalarda \%15'i aşırı eğitimli, yaklaşık \%16'sı eksik eğitimli ve \%68'i de yeterli eğitimli bulunmuşken ortalamaya göre yapılan hesaplamalarda ise yaklaşık olarak \%15'i aşırı eğitimli, \%11'i eksik eğitimli ve \%74'ünün de yeterli eğitim düzeylerine sahip oldukları tespit edilmiştir.

Tablo: 6

Türkiye'de 2014-2018 yıllarında Hanehalkı İşgücü Anketine Göre Kayıtlı ve İstihdamda Olanların 0.80 Yüzdelik, Mod ve Ortalamaya Göre Ölçümlerin İstatistiksel Dağılımları

\begin{tabular}{|c|c|c|c|c|c|}
\hline & Gözlem & Ortalama & Standart Sapma & Minimum & Maksimum \\
\hline \multicolumn{6}{|l|}{ 80. Yüzdelik } \\
\hline Aşırı Eğitim & 312.954 & 0,1006 & 0,3008 & 0 & 1 \\
\hline Eksik Eğitim & 312.954 & 0,4774 & 0,4994 & 0 & 1 \\
\hline Yeterli Eğitim & 312.954 & 0,4218 & 0,4938 & 0 & 1 \\
\hline \multicolumn{6}{|l|}{ Mod } \\
\hline Aşırı Eğitim & 312.954 & 0,1539 & 0,3609 & 0 & 1 \\
\hline Eksik Eğitim & 312.954 & 0,1642 & 0,3705 & 0 & 1 \\
\hline Yeterli Eğitim & 312.954 & 0,6817 & 0,4657 & 0 & 1 \\
\hline \multicolumn{6}{|l|}{ Ortalama } \\
\hline Aşırı Eğitim & 312.954 & 0,1498 & 0,3569 & 0 & 1 \\
\hline Eksik Eğitim & 312.954 & 0,1072 & 0,3094 & 0 & 1 \\
\hline Yeterli Eğitim & 312.954 & 0,7428 & 0,4370 & 0 & 1 \\
\hline
\end{tabular}

Not: 80. yüzdelik için mod ve ortalama yazarlar tarafindan hesaplanmıştır.

Çalışmamızda aşırı eğitimliliğin yukarıdaki hangi teorilerin etkisinde kaldıkları izleyen kısımda açıklanmaya çalışılacaktır. 


\section{Yöntem}

\subsection{Ekonometrik Modellemeye İliş̧kin Teorik Çerçeve}

Çalışmanın iki hipotezi vardır. İlk hipotezde bireyin deneyiminde meydana gelecek bir artışın aşırı eğitimlilik üzerinde negatif bir etki yaratacağı varsayılmaktadır. "Beşerî Sermaye Teorisi"nde bireylerin nitelik ve becerileri eğitim yoluyla daha üst düzeylere çıkarılarak verimlilik düzeyleri arttırılır. Bilgi, beceri ve niteliklere işgücü piyasasında önem verilir. Uyumsuz eşleşme kısa vadede söz konusu olup geçici durum olarak değerlendirilir, arz ve talebin uyarlama süreci sonunda ortadan kalkar (Becker, 1964). Sicherman ve Galor'un Kariyer Hareketliliği Teorisine göre de mezunların mesleki kariyerine genellikle fazla kalifiye oldukları bir işle başladığı belirtilirken, daha yaşlı çalışanlar başlangıçtaki mesleki eğitimde edindikleri becerilerin sürekliliği sorunu ile de karşı karşıya kalmaktadır. $\mathrm{Bu}$ teoriye bağlı olarak aşırı eğitimlilik yaş ilerledikçe işgücü piyasası tecrübesine bağlı olarak azalır (Sicherman \& Galor, 1990: 101-22; Kurnaz, 2015: 96).

İkinci hipotez bireyin eğitim düzeyi ile ilgilidir. Eğitim düzeyi arttıkça aşırı eğitimlilik artmaktadır. "İ̧̧ Rekabeti Teorisi” (Kuyruk Teorisi)'ne göre bireylerin işgücü piyasasında, konumlarını belirleyen unsur eğitim seviyesidir ve eğitim maliyetleri dikkate alınır. Kuyruk hipotezine göre eğitimin verimliliğe etkisi doğrudan değil dolaylıdır. Teoride iş talep edenler mevcut iş imkânı için kuyruğa girerler. Diploma, kuyruğun başında bulunabilmek amacıyla rekabet aracı konumundadır. Eğitim düzeyi yüksek olan kişi kuyruğun başında yer alır (Thurow, 1974; Carnoy, 1989; Ünal, 1996: 123-24).

Aşağıda sırasıyla önce aşırı eğitimlilik Probit modeliyle, izleyen kısımda da iki değişkenli probit modeliyle anlatılacaktır.

\subsubsection{Probit Model}

Eğitimdeki uyumsuzluğun belirleyicilerini tanımlamanın basit bir yolu, aşırı eğitim için doğrusal bir indeks fonksiyonu ve bir ilave hata terimi $\varepsilon_{\mathrm{i}}$ ile ilişkili olan gizli bir sürekli (gözlemlenmemiş) değişken $\mathrm{Y}_{\mathrm{i}}{ }^{*}$ 'yi oluşturmaktır.

$$
Y_{i}^{*}=\beta X_{i}+\varepsilon_{i}
$$

Birey i'nin aşırı eğitimli olup olmadığına dair gizli değişken $Y_{i}$ *'nin gözlemlenen ikilinin gerçekleşmesi aşağıdaki forma sahiptir:

$$
\begin{aligned}
& Y_{i}=1 \text { ĕger kişi aşırı ĕ̆itimli ise }\left(Y_{i}^{*}>0\right) \\
& Y_{i}=0 \text { diğer durumlar }
\end{aligned}
$$

Böylece, aşırı eğitimin belirleyicileri iki değerli bir probit denklemiyle tahmin edilebilir. Yukarıda denklem 1'de $\mathrm{X}_{\mathrm{i}}$ bireysel özelliklerin bir vektörüdür (yaş, yaşkare, eğitim durumu, deneyim, cinsiyet, eğitim durumu, işteki durum, özel sektörde olup olmama durumu, evli olup olmama durumu, çalışan sayısı, sektörler, bölgeler ve yıllar). $\varepsilon_{i}$ sıfır ortalama, birim varyansla normal dağılan hata terimidir. 
Kantarmacı, S. \& S. Demirogları \& H. Erk \& Ş. Üçdoğruk-Birecikli (2021), "Türkiye İşgücü Piyasasında Bireylerin Aşırı Eğitimliliğinin Ölçülmesi: İki Değişkenli Probit Model Uygulaması”, Sosyoekonomi, 29(48), 271-292.

\subsection{2. İki Değişkenli Probit Model}

Aşırı eğitimlilik, bireyin mevcut işinde olması gerekenden daha fazla eğitim seviyesine sahip olması olarak tanımlanır. Aşırı eğitimli olma ihtimalini etkileyen birçok faktör vardır. Örneğin yaş, cinsiyet, eğitim ve deneyim önemlidir (Becker, 1991). İşgücü piyasasına tam olarak katılma becerisi eksikliği, bazı bireylerin kendilerini aşırı eğitimde değerlendirmelerini daha olası kılabilir. İstihdam firsatlarının mevcudiyeti ve aşırı eğitim arasındaki ilişki basit değildir. İstihdam edilenler seçici bir gruptur ve seçim sürecinin de aşırı eğitimle ilgili olduğu varsayılabilir. Uygun bir istihdam mevcut değilse, aşırı eğitimden kaçınmak için işsizlik de bir strateji olarak seçilebilir. Aşırı eğitimli olma olasıllı̆ı en yüksek olanlar istihdama girme olasıllğ 1 en düşük olanlar olduğundan örneklemin istihdamda olanlarla sınırlandırılması, aşırı eğitimin analiz edilmesinde sapmalı sonuçlara yol açabilir (Büchel \& Van Ham, 2003: 482-93).

İlk adımda, Sosyal Güvenlik Kurumu'na kayıtlı aktif işgücünde istihdamda olan veya olmayan bireyler vardır. İş özelliklerine ilişkin herhangi bir değişken seçim modeline ait denkleme dâhil edilememiştir. Çünkü işsizlerin tanımlanacak bir işi yoktur. Buna karşın Sosyal Güvenlik Kurumu'na kayıtlı istihdamda olan bireyler tanımlanabilir. İkinci adımda, aşırı eğitimli olma olasılığı yalnızca örnekteki çalışan bireyler için analiz edilmektedir. Seçim denkleminde olan ancak ana denklemde olmayan en az bir değişkenin araç olarak seçilmesi gerekmektedir. Bir başka deyişle istihdam edilme olasılığını etkileyen ancak aşırı eğitim olasılığını etkilemediği düşünülen araç değişkenler medeni durum (evli) ve evli kadınlara ait etkileşim terimi olarak seçilmiştir. Evli olmak, iş bulma olasılığını arttırmakta ve aile yaşamını sürdürme konusunda bir önem ifade etmektedir. Ayrıca kadınların işe girmesi erkeklere göre daha dezavantajlıdır. Benzer sonucu Ermini vd., 2017'de bulmuştur.

Aşırı eğitimli olanlar, istihdamda kayıtlı çalışan bireylerin örnekleminin bir alt kümesidir. Bir işe sahip olmak, iş aramanın kalitesini etkilediği için, çalışan bireyin kendi yapacağ1 seçimi de aşırı eğitimin özelliklerini gösterecektir. Yani hem işgücü piyasasına katılma kararını hem de aşırı eğitimlilik durumunu etkileyen gözlemlenemeyen faktörler söz konusudur. Bu potansiyel seçim yanlılı̆̆ını hesaba katmak için, çalışmada Heckman (1979) seçim modelinin bir çeşidi kullanılmıştır. Seçim (Sosyal Güvenlik Kurumu'na kayıtlı istihdamda olan veya olmayan) ve ana denklemdeki (aşırı eğitimli olan veya olmayan) bağımlı değişkenler ikili olduğundan, Van de Ven vd., (1981) önerdiği maksimum olasılık tahmini ile örneklem seçimli iki değişkenli probit modeli tercih edilmiştir. İki denklem arasındaki kritik ilişki, ana denklemin hata terimlerinin korelasyonudur. Korelasyonun varlığı anlamlı bir Wald testi ile belirlenmektedir.

Örnek seçimine sahip iki değişkenli probit modelinde aşağıdaki ilişki varsayılmaktadır:

$$
\text { aşırl ĕ̆itimlilik } k_{j}^{*}=\beta X_{j}+u_{l j}
$$

ikili sonuç gözlemlendiğinde;

$$
\text { aşırı eğitimlilik } \text { probit }_{j}\left(\text { aşırı eğitimlilik }{ }_{j}^{*}>0\right)
$$


bağımlı değişken olan aşırı eğitimlilik, her zaman gözlenemez; ve gözlem j için bağımlı değişken aşağıdaki gibi olur:

$$
S G K-\text { istihdamda olan }{ }_{j}^{\text {seçim }}=\left(Z_{j} \gamma+u_{2 j}>0\right)
$$

Denklem (2)'de $X_{j}$ kadın, yaş, yaşkare, eğitim, deneyim, işteki durum, özel sektörde olup olmama durumu, medeni durum, firmada çalışan kişi sayısı, sektör ve bölge oranlarını içerirken, Denklem (4)'teki, $Z_{j}$ yaş, yaşkare, eğitim, medeni durum, evli kadın ve 2014-2018 yıl kuklalarını içermektedir. Aşağıda;

$$
\begin{aligned}
& u_{1} \sim \mathrm{N}(0,1) \\
& u_{2} \sim \mathrm{N}(0,1) \\
& \operatorname{cor}\left(u_{1}, u_{2}\right)=\rho \text { dur. }
\end{aligned}
$$

$\rho$ sıfırdan farklı olduğunda (1) numaralı standart probit denklemi sapmalı tahminlerde bulunacaktır. Örnek seçimli probit modeli, modeldeki tüm parametreler için tutarlı, asimptotik etkin tahminler sağlamaktadır. Yukarıda da belirtildiği gibi, (4) numaralı seçim denklemine, medeni durum ve evli kadınlara ait etkileşim terimi, araç değişken olarak eklenmiştir. Bu araç değişkenler, Denklem (3) 'de bulunmamaktadır. İzleyen kısımda model tahmin sonuçları verilecektir (Bonnal vd., 2009; StataCorp, 2007). Modellerde, işgücü piyasası ile aşırı eğitimlilik karakteristikleri aynı anda üç farklı istatistik yöntemle ölçülecektir. Çalışmanın amacı, Türkiye'de 15-65 yaş aralığındaki Sosyal Güvenlik Kurumuna kayıtlı istihdamda bulunan kişilerin aşırı eğitimli olma olasılıklarını incelemektir. Bu verilerle, işgücü ile aşırı eğitimlilik arasındaki ilişki tanımlanacak ve Türkiye’deki durum irdelenmeye çalışılacaktır.

\subsection{Veriler ve Tanımlayıcı İstatistikler}

2014-2018 yılları arasındaki Türkiye Hanehalkı İşgücü Anketi ham verileri birleştirilerek 15-65 yaşlarındaki havuzlanmış 963328 bireyle çalışılmıştır. Bireyin ISCO 08 ve eğitim bilgileri kullanılarak aşırı eğitim değişkeni oluşturulmuştur. Aşırı eğitimlilik denklemi ile ilgili olan değişkenler kadın, yaş, yaşkare, eğitimi, deneyimi, işteki durumu, özel sektörde olup olmama durumu, medeni durumu, firmada çalışan kişi sayısı, sektör ve bölgelerdir. İstihdam sektör denklemini etkileyen değişkenler ise yaş, yaşkare, eğitim, medeni durumu, evli kadın ve yıl değişkenleridir. Aşırı eğitimli olan/olmayan ve Sosyal Güvenlik Kurumu'na kayıtlı istihdamda olan /olmayan bireyler aşağıda Tablo 7'de birlikte değerlendirilmiştir.

\section{Tablo: 7}

Tanımlayıcı İstatistikler

\begin{tabular}{|l|c|c|}
\hline & \multicolumn{2}{|c|}{ Ortalama } \\
\hline Sürekli Değişkenler & \multicolumn{2}{|c|}{} \\
\hline Yaş & 34,3393 & 12,1318 \\
\hline Yaşkare & 1326,375 & 868,3926 \\
\hline Eğitim Durumu & 2,0076 & 1,3067 \\
\hline Deneyim & 7,7906 & \\
\hline Kadın*evli & 0,3429 & 8,9262 \\
\hline
\end{tabular}


Kantarmacı, S. \& S. Demirogları \& H. Erk \& Ş. Üçdoğruk-Birecikli (2021), "Türkiye İşgücü Piyasasında Bireylerin Aşırı Eğitimliliğinin Ölçülmesi: İki Değişkenli Probit Model Uygulaması”, Sosyoekonomi, 29(48), 271-292.

\begin{tabular}{|c|c|c|}
\hline \multicolumn{3}{|l|}{ Kukla Değişkenler } \\
\hline \multicolumn{3}{|l|}{ SGK-İstihdam Durumu } \\
\hline SGK Kayıtlı İstihdamda Olan & 0,3249 & 0,4683 \\
\hline SGK Kayıtlı İstihdam Olmayan & 0,6751 & 0,4683 \\
\hline \multicolumn{3}{|l|}{ Cinsiyet (T.S.: Erkek) } \\
\hline Erkek & 0,4902 & 0,4999 \\
\hline Kadın & 0,5098 & 0,4999 \\
\hline \multicolumn{3}{|l|}{ Medeni Durum (T.S.: Bekâr) } \\
\hline Bekâr & 0,3177 & 0,4655 \\
\hline Evli & 0,6456 & 0,4783 \\
\hline Boşanmış & 0,0233 & 0,1509 \\
\hline Eşi Ölmüş & 0,0134 & 0,1149 \\
\hline \multicolumn{3}{|l|}{ Çalıșan Sayısı (T.S.: 20-49 Kiși) } \\
\hline $0-10$ & 0,5696 & 0,4951 \\
\hline $11-19$ & 0,0507 & 0,2193 \\
\hline $20-49$ & 0,1306 & 0,3369 \\
\hline$>50$ & 0,2422 & 0,4284 \\
\hline Bilmiyor >10 & 0,0069 & 0,0827 \\
\hline \multicolumn{3}{|l|}{ İşteki durumu (T.S.: İşveren) } \\
\hline İşveren & 0,0210 & 0,1432 \\
\hline Ücretli çalışan & 0,3491 & 0,4766 \\
\hline Kendi hesabına çalışan & 0,0844 & 0,2779 \\
\hline Ücretsiz aile işçisi & 0,0747 & 0,2629 \\
\hline Çalışmayan & 0,4708 & 0,4991 \\
\hline \multicolumn{3}{|l|}{ İşyeri Statüsü (T.S.: Kamu) } \\
\hline Kamu & 0,1468 & 0,3538 \\
\hline Özel sektör & 0,8532 & 0,3538 \\
\hline \multicolumn{3}{|l|}{ Sektörler (T.S.: Ínşaat) } \\
\hline İnşaat & 0,0398 & 0,1955 \\
\hline Tarım & 0,1151 & 0,3192 \\
\hline İmalat & 0,0918 & 0,2888 \\
\hline Maden & 0,0014 & 0,0386 \\
\hline Hizmet & 0,2666 & 0,4422 \\
\hline \multicolumn{3}{|c|}{ Bölgeler (T.S.: Güneydoğu Anadolu) } \\
\hline Güneydoğu Anadolu & 0,1008 & 0,3011 \\
\hline İstanbul & 0,0973 & 0,2964 \\
\hline Batı Marmara & 0,0640 & 0,2447 \\
\hline Ege & 0,1141 & 0,3178 \\
\hline Doğu Marmara & 0,0815 & 0,2735 \\
\hline Batı Anadolu & 0,1129 & 0,3164 \\
\hline Akdeniz & 0,1124 & 0,3158 \\
\hline Orta Anadolu & 0,0647 & 0,2460 \\
\hline Bat1 Karadeniz & 0,0807 & 0,2723 \\
\hline Doğu Karadeniz & 0,0412 & 0,1988 \\
\hline Kuzeydoğu Anadolu & 0,0589 & 0,2354 \\
\hline Ortadoğu Anadolu & 0,0715 & 0,2575 \\
\hline \multicolumn{3}{|l|}{ Yillar (T.S.: YIl 2017) } \\
\hline Y11 2014 & 0,3074 & 0,4614 \\
\hline Y11 2015 & 0,3017 & 0,4590 \\
\hline Y1l 2016 & 0,2911 & 0,4543 \\
\hline Y11 2017 & 0,0499 & 0,2176 \\
\hline Y11 2018 & 0,0499 & 0,2177 \\
\hline Gözlem Sayısı & & 963.328 \\
\hline
\end{tabular}

Tablo 7'de Tanımlayıcı İstatistikler incelendiğinde, çalışma kapsamında bireylerin ortalama yaşının 34,3393 olduğu görülmektedir. İşteki deneyim ortalama 7,7906 yıl iken kişilerin \%32,49’u Sosyal Güvenlik Kurumuna kayıtlı ve istihdamdadır. Çalışmada erkekler \%49,02 iken kadınlar \%50,98 olarak bulunmuştur. Medeni durumda en fazla \%64,56 ile evlilerindir. Kişilerin \%34,29’u evli kadındır. Örneklemin \%85,32 özel sektörde istihdamda olup en fazla ücretli çalışan mevcuttur. Daha çok küçük işletmelerde çalışmaktadırlar. Sektör pay1 en yüksek hizmetlerdedir. Bölge gruplarına ait en yüksek yüzde, 11,41 ile Ege'de iken en düşük yüzde, 4,12 ile Doğu Karadeniz'dedir. 


\subsection{Tahmin Sonuçlarının Yorumlanması}

Aşırı eğitimliliğin ölçülmesinde 2.1. alt başlığında bahsedildiği üzere, literatürde yer alan istatistiksel yöntemlerden 80. yüzdelik, ortalama ve mod ayrı ayrı kullanılmıştır. Aşağıda Tablo 8-9'da probit ve iki değişkenli probit model sonuçları ve marjinal etkiler verilmiştir. Yorumlamalar, bağımlı değişkeni moda göre hesaplanmış model sonuçları üzerinden yapılmıştır. Tablo 8 incelendiğinde modelin açıklama gücünü veren iyi uyum ölçütü Pseudo $\mathrm{R}^{2}$ değeri 0,3099 olarak elde edilmiştir. Modelin anlamlılığını veren LR istatistik değeri 98097,07 ve olasılık değeri 0,000 olarak elde edilmiştir. Model istatistiki olarak anlamlıdır.

\section{Tablo: 8}

Probit Model Tahmin Sonuçları

\begin{tabular}{|c|c|c|c|c|c|c|}
\hline & \multicolumn{2}{|c|}{0.80 Yüzdelik } & \multicolumn{2}{|r|}{ Mod } & \multicolumn{2}{|c|}{ Ortalama } \\
\hline Bağımlı Değişken: Aşırı Eğitimlilik & Katsayı & Marjinal Etki & Katsayı & Marjinal Etki & Katsayı & Marjinal Etki \\
\hline Sabit & $-7,9828^{*}$ & - & $-4,7957^{*}$ & - & $-5,3705^{*}$ & - \\
\hline \multicolumn{7}{|l|}{ Sürekli Değişkenler } \\
\hline Yas & $0,0299^{*}$ & $0,0000^{*}$ & $0,0535^{*}$ & $0,0037^{*}$ & $0,0400^{*}$ & $0,0015^{*}$ \\
\hline Yaskare & $-0,0006^{*}$ & $-3,31 \mathrm{e}^{-07^{*}}$ & $-0,0007^{*}$ & $-0,0000^{*}$ & $-0,0005^{*}$ & $-0,0000^{*}$ \\
\hline Eğitim Düzeyi & $1,6006^{*}$ & $0,0008^{*}$ & $0,7430^{*}$ & $0,0522^{*}$ & $0,9119^{*}$ & $0,0349^{*}$ \\
\hline Deneyim & $0,0059^{*}$ & $3,20 \mathrm{e}^{-06^{*}}$ & $-0,0023^{*}$ & $-0,0001^{*}$ & $-0,0099^{*}$ & $-0,0003^{*}$ \\
\hline \multicolumn{7}{|l|}{ Kukla Değișkenler } \\
\hline \multicolumn{7}{|l|}{ Cinsiyet (T.S.: Erkek) } \\
\hline Kadın & $-0,4928^{*}$ & $-0,0002^{*}$ & $-0,5028^{*}$ & $-0,0353^{*}$ & $-0,4849^{*}$ & $-0,0184^{*}$ \\
\hline \multicolumn{7}{|l|}{ Medeni Durum (T.S.: Bekâr) } \\
\hline Evli & $-0,0390^{*}$ & $-0,0000^{*}$ & $0,0791^{*}$ & $0,0055^{*}$ & $0,0198^{* *}$ & $0,0007^{* *}$ \\
\hline \multicolumn{7}{|l|}{ İşteki durumu (T.S.: İşveren) } \\
\hline Ücretli çalışan & $-0,0429^{* *}$ & $-0,0000^{* *}$ & $0,2403^{*}$ & $0,0169^{*}$ & $0,2334^{*}$ & $0,0088^{*}$ \\
\hline Kendi hesabına çalışan & $0,1107^{*}$ & $0,0000^{*}$ & $0,3287^{*}$ & $0,0231^{*}$ & $0,2501^{*}$ & $0,0095^{*}$ \\
\hline Ücretsiz aile işçisi & $-0,9719^{*}$ & $-0,0005^{*}$ & $-0,2720^{*}$ & $-0,0191^{*}$ & $-0,3750^{*}$ & $-0,0142^{*}$ \\
\hline \multicolumn{7}{|l|}{ İşyeri Statüsü (T.S.: Kamu) } \\
\hline Özel sektör & $0,2512^{*}$ & $0,0001^{*}$ & $0,4679^{*}$ & $0,0329^{*}$ & $0,3639^{*}$ & $0,0138^{*}$ \\
\hline \multicolumn{7}{|l|}{ Çalışan Sayısı (T.S.: 20-49 Kişi) } \\
\hline 10 ve daha az kişi & $0,1157^{*}$ & $0,0000^{*}$ & $-0,0974^{*}$ & $-0,0068^{*}$ & $-0,0789^{*}$ & $-0,0030^{*}$ \\
\hline Bilmiyor, fakat 10 'dan fazla kişi & $0,2669^{*}$ & $0,0001^{*}$ & $0,0690^{* * * *}$ & $0,0048^{* * *}$ & $0,1526^{*}$ & $0,0058^{*}$ \\
\hline 11-19 kişi & $-0,0101$ & $-5,49 \mathrm{e}^{-06}$ & $-0,0741^{*}$ & $-0,0052^{*}$ & $-0,0986^{*}$ & $-0,0037^{*}$ \\
\hline 50 veya daha fazla kişi & $0,2713^{*}$ & $0,0001^{*}$ & $0,1467^{*}$ & $0,0103^{*}$ & $0,2247^{*}$ & $0,0085^{*}$ \\
\hline \multicolumn{7}{|l|}{ Sektörler (T.S.: İnşaat) } \\
\hline Tarım & $1,5414^{*}$ & $0,0008^{*}$ & $0,3797^{*}$ & $0,0267^{*}$ & $0,5181^{*}$ & $0,0196^{*}$ \\
\hline İmalat & $0,2932^{*}$ & $0,0001^{*}$ & $0,2471^{*}$ & $0,0173^{*}$ & $0,3258^{*}$ & $0,0123^{*}$ \\
\hline Maden & 0,0759 & 0,0000 & $0,3101^{*}$ & $0,0218^{*}$ & $0,5967^{*}$ & $0,0226^{*}$ \\
\hline Hizmet & $0,2994^{*}$ & $0,0001^{*}$ & $-0,5912^{*}$ & $-0,0416^{*}$ & 0,0003 & 0,0000 \\
\hline \multicolumn{7}{|l|}{ Bölgeler (T.S.: Güneydoğu Anadolu_) } \\
\hline İstanbul & $-0,0880^{*}$ & $-0,0000^{*}$ & $-0,0859^{*}$ & $-0,0060^{*}$ & $-0,1559^{*}$ & $-0,0059^{*}$ \\
\hline Batı Marmara & $0,1180^{*}$ & $0,0000^{*}$ & $0,2704^{*}$ & $0,0190^{*}$ & $0,1727^{*}$ & $0,0065^{*}$ \\
\hline Ege & $0,1116^{*}$ & $0,0000^{*}$ & $0,1669^{*}$ & $0,0117^{*}$ & $0,1250^{*}$ & $0,0047^{*}$ \\
\hline Doğu Marmara & $0,0647^{*}$ & $0,0000^{*}$ & $0,1996^{*}$ & $0,0140^{*}$ & $0,1051^{*}$ & $0,0039^{*}$ \\
\hline Batı Anadolu & 0,0237 & 0,0000 & $0,1072^{*}$ & $0,0075^{*}$ & 0,0100 & 0,0003 \\
\hline Akdeniz & $0,1010^{*}$ & $0,0000^{*}$ & $0,1102^{*}$ & $0,0077^{*}$ & $0,0749^{*}$ & $0,0028^{*}$ \\
\hline Orta Anadolu & $0,1460^{*}$ & $0,0000^{*}$ & $0,3030^{*}$ & $0,0213^{*}$ & $0,1699^{*}$ & $0,0064^{*}$ \\
\hline Bat1 Karadeniz & $0,0884^{*}$ & $0,0000^{*}$ & $0,2571^{*}$ & $0,0181^{*}$ & $0,1324^{*}$ & $0,0050^{*}$ \\
\hline Doğu Karadeniz & 0,0314 & 0,0000 & $0,1522^{*}$ & $0,0107^{*}$ & $0,1368^{*}$ & $0,0052^{*}$ \\
\hline Kuzeydoğu Anadolu & $0,0631^{* *}$ & $0,0000^{* *}$ & $0,1386^{*}$ & $0,0097^{*}$ & $0,0777^{*}$ & $0,0029^{*}$ \\
\hline Ortadoğu Anadolu & 0,0418 & 0,0000 & $0,0580^{*}$ & $0,0040^{*}$ & $0,0626^{*}$ & $0,0023^{*}$ \\
\hline \multicolumn{7}{|l|}{ Yıllar (T.S.: Yıl 2017) } \\
\hline Y1l 2014 & $-0,0794^{*}$ & $-0,0000^{*}$ & $0,0259^{* * * *}$ & $0,0018^{* * * *}$ & $-0,0380^{* *}$ & $-0,0014^{* *}$ \\
\hline Y11 2015 & $-0,0341^{* * *}$ & $-0,0000^{* * * *}$ & $0,0300^{* * *}$ & $0,0021^{* *}$ & $-0,0122$ & $-0,0004$ \\
\hline Y11 2016 & $-0,0347^{* * *}$ & $-0,0000^{* * *}$ & 0,0195 & 0,0013 & \begin{tabular}{|l}
$-0,0063$ \\
\end{tabular} & $-0,0002$ \\
\hline Y11 2018 & $-0,7478^{*}$ & $-0,0004^{*}$ & $-0,2449^{*}$ & $-0,0172^{*}$ & $-0,3408^{*}$ & $-0,0129^{*}$ \\
\hline $\begin{array}{l}\text { LR } \chi^{2}: \\
\text { Prob: }\end{array}$ & \multicolumn{2}{|l|}{$\begin{array}{l}125008.92 \\
0,0000\end{array}$} & \multicolumn{2}{|l|}{$\begin{array}{l}98097,07 \\
0,0000\end{array}$} & \multicolumn{2}{|l|}{$\begin{array}{l}115263,34 \\
0,0000\end{array}$} \\
\hline Pseudo $\mathbf{R}^{2}$ : & 0,5324 & & 0.3099 & & 0,3709 & \\
\hline \multicolumn{5}{|l|}{ Gözlem Sayısı: } & \multicolumn{2}{|c|}{497.437} \\
\hline
\end{tabular}


Yukarıda Tablo 8 ile yaş, deneyim gibi değişkenlerin aşırı eğitimli olma olasılığı üzerindeki etkileri probit model ile özetlenmiştir. Tablo 9'da Türkiye'de SGK'ya kayıtlı istihdamda olan bireylerle aşırı eğitim arasındaki ilişki Heckman iki değişkenli probit modeliyle incelenmiş ve sonuçları verilmiştir. $\rho$ değeri aşırı eğitimlilik ve SGK'ya kayıtlı istihdamda olanların denklemlerinde yer alan hata terimleri arasındaki korelasyonu ölçmektedir. $\rho,-0,1350$ olarak elde edilmiştir. Bu sonuç, her iki denklemin hata terimleri arasında sıfırdan farklı bir korelasyon olduğunu ifade etmektedir. $\rho$ 'nun bağımsızlık sınamasında ise LR test değeri 37,71ve olasılık değeri 0,0000 olarak elde edilmiştir. Her iki bağımlı değişkenin birbiriyle ilişkili olduğu ve modelin iki değişkenli probit model kullanılarak analiz edilmesi gerektiğini göstermektedir. Aşırı eğitimlilik ve SGK'ya kayıtlı istihdamda olanların denklemlerinin birbirinden bağımsız olup olmadığını gösteren Wald istatistik değeri ise 41352,87 ve olasılık değeri 0,0000 olarak elde edilmiştir. Wald testi sonucuna göre de iki denklem birlikte değerlendirilmelidir.

Tablo: 9

\section{Heckman İki Değișkenli Probit Modelinin Tahmin Sonuçları}

\begin{tabular}{|c|c|c|c|c|c|c|}
\hline & \multicolumn{2}{|c|}{0.80 Yüzdelik } & \multicolumn{2}{|c|}{ Mod } & \multicolumn{2}{|c|}{ Ortalama } \\
\hline & Katsayı & Marjinal Etki & Katsayı & Marjinal Etki & Katsayı & Marjinal Etki \\
\hline \multicolumn{7}{|l|}{$\begin{array}{l}\text { Aşırı Eğitimlilik Denklemi } \\
\text { Bağımlı değișken: Aşırı eğitimli }\end{array}$} \\
\hline Sabit & $-10,2221^{*}$ & - & $-3.4536^{*}$ & - & $-4,6376^{*}$ & - \\
\hline \multicolumn{7}{|l|}{ Sürekli Değişkenler } \\
\hline Yaş & $-0,1169^{*}$ & $-0,0046^{*}$ & $-0,0211^{*}$ & $-0,0002$ & $-0,0230^{*}$ & $-0,0019^{*}$ \\
\hline Yaşkare & $0,0013^{*}$ & $0,0000^{*}$ & $0,0003^{*}$ & $0,0000^{* *}$ & $0,0004^{*}$ & $0,0000^{*}$ \\
\hline Eğitim Düzeyi & $2,8113^{*}$ & $0,1613^{*}$ & $0,8116^{*}$ & $0,1323^{*}$ & $1,0391^{*}$ & $0,1340^{*}$ \\
\hline Deneyim & 0,0001 & $7,34 \mathrm{e}^{-06}$ & $-0,0130^{*}$ & $-0,0020^{*}$ & $-0,0191^{*}$ & $-0,0024^{*}$ \\
\hline \multicolumn{7}{|l|}{ Kukla Değişkenler } \\
\hline \multicolumn{7}{|l|}{ Cinsiyet (T.S.: Erkek) } \\
\hline Kadın & $-0,4872^{*}$ & $-0,0274^{*}$ & $-0,4387^{*}$ & $-0,0692^{*}$ & $-0,4762^{*}$ & $-0,0608^{*}$ \\
\hline \multicolumn{7}{|l|}{ İşteki durumu (T.S.: İşveren) } \\
\hline Ücretli çalışan & $0,0898^{*}$ & $0,0050^{*}$ & $0,3427^{*}$ & $0,0540^{*}$ & $0,3370^{*}$ & $0,0430^{*}$ \\
\hline Kendi hesabına çalışan & $0,7960^{*}$ & $0,0449^{*}$ & $0,6080^{*}$ & $0,0959^{*}$ & $0,5495^{*}$ & $0,0702^{*}$ \\
\hline Ücretsiz aile işçisi & $0,8820^{*}$ & $0,0497^{*}$ & $0,7935^{*}$ & $0,1252^{*}$ & $0,6684^{*}$ & $0,0854^{*}$ \\
\hline \multicolumn{7}{|l|}{ İşyeri Statüsü (T.S.: Kamu) } \\
\hline Özel sektör & $0,3336^{*}$ & $0,0188^{*}$ & $0,4335^{*}$ & $0,0684^{*}$ & $0,3583^{*}$ & $0,0457^{*}$ \\
\hline \multicolumn{7}{|l|}{ Çalışan Sayısı (T.S.: 20-49 Kişi) } \\
\hline 10 ve daha az kişi & $0,3095^{*}$ & $0,0174^{*}$ & $0,0602^{*}$ & $0,0095^{*}$ & $0,0482^{*}$ & $0,0061^{*}$ \\
\hline Bilmiyor, fakat 10 'dan fazla kişi & $0,2996^{*}$ & $0,0169^{*}$ & $0,1437^{*}$ & $0,0226^{*}$ & $0,1990^{*}$ & $0,0254^{*}$ \\
\hline 11-19 kişi & $-0,0173$ & $-0,0009$ & $-0,0555^{*}$ & $-0,0087^{*}$ & $-0,0980^{*}$ & $-0,0125^{*}$ \\
\hline 50 veya daha fazla kişi & $0,2814^{*}$ & $0,0158^{*}$ & $0,1367^{*}$ & $0,0215^{*}$ & $0,2193^{*}$ & $0,0280^{*}$ \\
\hline \multicolumn{7}{|l|}{ Sektörler (T.S.: İnşaat) } \\
\hline Tarım & $3,3180^{*}$ & $0,1872^{*}$ & $0,9278^{*}$ & $0,1464^{*}$ & $1,0767^{*}$ & $0,1375^{*}$ \\
\hline İmalat & $0,3346^{*}$ & $0,0188^{*}$ & $0,2229^{*}$ & $0,0351^{*}$ & $0,3174^{*}$ & $0,0405^{*}$ \\
\hline Maden & 0,0816 & 0,0046 & $0,2933^{*}$ & $0,0463^{*}$ & $0,6149^{*}$ & $0,0785^{*}$ \\
\hline Hizmet & $0,2519^{*}$ & $0,0142^{*}$ & $-0,7527^{*}$ & $-0,1182^{*}$ & $-0,0848^{*}$ & $-0,0108^{*}$ \\
\hline \multicolumn{7}{|l|}{$\begin{array}{l}\text { Bölgeler (T.S.: } \quad \text { Güneydoğu } \\
\text { Anadolu_) }\end{array}$} \\
\hline İstanbul & $-0,2273^{*}$ & $-0,0128^{*}$ & $-0,1950^{*}$ & $-0,0307^{*}$ & $-0,2468^{*}$ & $-0,0315^{*}$ \\
\hline Batı Marmara & $0,0920^{*}$ & $0,0051^{*}$ & $0,1886^{*}$ & $0,0297^{*}$ & $0,1245^{*}$ & $0,0159^{*}$ \\
\hline Ege & $0,0432^{* * *}$ & $0,0024^{* * *}$ & $0,0450^{*}$ & $0,0071^{*}$ & $0,0499^{*}$ & $0,0063^{*}$ \\
\hline Doğu Marmara & 0,0217 & 0,0012 & $0,1104^{*}$ & $0,0174^{*}$ & $0,0467^{*}$ & $0,0059^{*}$ \\
\hline Bat1 Anadolu & $-0,0513^{* * *}$ & $-0,0028^{* *}$ & $0,0303^{* *}$ & $0,0047^{* * *}$ & $-0,0446^{* *}$ & $-0,0057^{* *}$ \\
\hline Akdeniz & $0,1531^{*}$ & $0,0086^{*}$ & $0,0644^{*}$ & $0,0101^{*}$ & $0,0617^{*}$ & $0,0078^{*}$ \\
\hline Orta Anadolu & $0,0802^{*}$ & $0,0045^{*}$ & $0,1895^{*}$ & $0,0299^{*}$ & $0,0928^{*}$ & $0,0118^{*}$ \\
\hline Bat1 Karadeniz & 0,0339 & 0,0019 & $0,1690^{*}$ & $0,0266^{*}$ & $0,0739^{*}$ & $0,0094^{*}$ \\
\hline Doğu Karadeniz & $0,1038^{*}$ & $0,0058^{*}$ & $0,2043^{*}$ & $0,0322^{*}$ & $0,1426^{*}$ & $0,0182^{*}$ \\
\hline Kuzeydoğu Anadolu & $0,1714^{*}$ & $0,0096^{*}$ & $0,2063^{*}$ & $0,0325^{*}$ & $0,1104^{*}$ & $0,0141^{*}$ \\
\hline Ortadoğu Anadolu & $0,1379^{*}$ & $0,0077^{*}$ & $0,1254^{*}$ & $0,0197^{*}$ & $0,1111^{*}$ & $0,0142^{*}$ \\
\hline \multicolumn{7}{|c|}{$\begin{array}{l}\text { SGK'ya Kayıtlı İstihdam Denklemi } \\
\text { Bağımlı değişken: SGK'ya kayıtlı istihdamda olanlar }\end{array}$} \\
\hline Sabit & $-5,4026^{*}$ & - & $-5,4033^{*}$ & - & $-5,4034^{*}$ & - \\
\hline
\end{tabular}


Kantarmacı, S. \& S. Demirogları \& H. Erk \& Ş. Üçdoğruk-Birecikli (2021), "Türkiye İşgücü Piyasasında Bireylerin Aşırı Eğitimliliğinin Ölçülmesi: İki Değişkenli Probit Model Uygulaması”, Sosyoekonomi, 29(48), 271-292.

\begin{tabular}{|c|c|c|c|c|c|c|}
\hline \multicolumn{7}{|l|}{ Sürekli Değişkenler } \\
\hline Yaş & $0,2465^{*}$ & $-0,0046^{*}$ & $0,2464^{*}$ & $-0,0002$ & $0,2465^{*}$ & $-0,0019^{*}$ \\
\hline Yaşkare & $-0,0032^{*}$ & $0,0000^{*}$ & $-0,0032^{*}$ & $0,0000^{* *}$ & $-0,0032^{*}$ & $0,0000^{*}$ \\
\hline Eğitim Durumu & $0,3375^{*}$ & $0,1613^{*}$ & $0,3381^{*}$ & $0,1323^{*}$ & $0,3376^{*}$ & $0,1340^{*}$ \\
\hline Kadın*evli & $-1,4296^{*}$ & $-0,0112^{*}$ & $-1,4288^{*}$ & $-0,0179^{*}$ & $-1,4295^{*}$ & $-0,0055^{*}$ \\
\hline \multicolumn{7}{|l|}{ Kukla Değişkenler } \\
\hline \multicolumn{7}{|l|}{ Medeni Durum (T.S.: Bekâr) } \\
\hline Evli & $0,7267^{*}$ & $0,0057^{*}$ & $0,7279^{*}$ & $0,0091^{*}$ & $0,7269^{*}$ & $0,0027^{*}$ \\
\hline \multicolumn{7}{|l|}{ Yıllar (T.S.: Yıl 2017) } \\
\hline Y11 2014 & 0,0040 & 0,0000 & 0,0055 & 0,0000 & 0,0050 & 0,0000 \\
\hline Y11 2015 & $0,0327^{*}$ & $0,0002^{*}$ & $0,0337^{*}$ & $0,0004^{*}$ & $0,0333^{*}$ & $0,0001^{* *}$ \\
\hline Y11 2016 & $0,0223^{*}$ & $0,0001^{*}$ & $0,0232 *$ & $0,0002^{*}$ & $0,0229^{*}$ & $0,0000^{* *}$ \\
\hline Y11 2018 & $-0,1842^{*}$ & $-0,0014^{*}$ & $-0,1881^{*}$ & $-0,0023^{*}$ & $-0,1852^{*}$ & $-0,0007^{*}$ \\
\hline Rho(p): & \multirow{3}{*}{\multicolumn{2}{|c|}{$\begin{array}{c}-0,2692 \\
77,31 \\
0,0000\end{array}$}} & \multirow{3}{*}{\multicolumn{2}{|c|}{$\begin{array}{c}-0,1358 \\
37,71 \\
0,0000 \\
\end{array}$}} & \multirow{3}{*}{\multicolumn{2}{|c|}{$\begin{array}{c}-0,0551 \\
7,61 \\
0,0058\end{array}$}} \\
\hline Rho(p) Bağımsızlık Testi (LR): & & & & & & \\
\hline LR Prob: & & & & & & \\
\hline Wald: & \multirow{2}{*}{\multicolumn{2}{|c|}{$\begin{array}{c}19264,17 \\
0.0000\end{array}$}} & \multirow{2}{*}{\multicolumn{2}{|c|}{$\begin{array}{c}41352,87 \\
0,0000\end{array}$}} & \multirow{2}{*}{\multicolumn{2}{|c|}{36509,76}} \\
\hline Prob: & & & & & & 0,0000 \\
\hline \multirow{2}{*}{\multicolumn{5}{|c|}{$\begin{array}{l}\text { Gözlem Sayısı: } \\
\text { Selected: }\end{array}$}} & \multirow{2}{*}{\multicolumn{2}{|c|}{$\begin{array}{l}963,328 \\
312,954\end{array}$}} \\
\hline \multirow{2}{*}{\multicolumn{5}{|c|}{$\begin{array}{l}\text { Selected: } \\
\text { Nonselected: }\end{array}$}} & & \\
\hline & & & & & \multicolumn{2}{|c|}{$\begin{array}{l}312,954 \\
650,374\end{array}$} \\
\hline
\end{tabular}

Tablo 9'da verilen Heckman iki değişkenli probit model tahmin sonuçları incelendiğinde aşırı eğitimlilik ve seçim denkleminde yer alan yaş değişkeni katsayısının istatistiki olarak anlamlı olmasına rağmen marjinal etki katsayısının istatistiki olarak anlamsız olduğu görülmektedir. Deneyim değişkeni katsayısı ise "Kariyer Hareketliliği Teorisi" (Sicherman \& Galor, 1990) varsayımlarıyla tutarlı ve negatif elde edilmiştir. Bireyin iş deneyimi arttıkça aşırı eğitimli olma olasılığ $\% 0.2$ azalmaktadır. Tablo 8'de verilen probit modelde bağımlı değişken sadece iki durumludur. Sonuçlara bakıldığında yaş değişkeni katsayısının istatistiki olarak anlamlı ve pozitif, iş deneyimi katsayısının ise istatistiki olarak anlamlı ve negatif elde edildiği görülmektedir. Yaşın işaretinin iki değişkenli probit modelden farklı çıktığı görülmektedir. Bu sonuç gözlenemeyen etkinin hesaba katılmamasından veya çalıştığımız 2014-2018 yıllarında Türkiye'de işsizlik sorunun yaşanmasından kaynaklanabilmektedir.

İş rekabeti teorisine göre (Thurow, 1974) kişilerin iş bulma kuyruğundaki yerini eğitim seviyesi belirlemektedir. Bireyin eğitim düzeyi incelendiğinde Tablo 8 ve Tablo 9 ile verilen her iki modelde katsayının pozitif ve istatistiki olarak anlamlı olduğu görülmüştür. Marjinal etki katsayısı değerlendirildiğinde eğitim seviyesi arttıcça aşırı eğitimli olma olasılığının Tablo 8 ile verilen modelde $\% 5$, Tablo 9 ile verilen modelde ise $\% 13$ artacağ görülmektedir. Bu sonuç artan eğitim seviyesinin bir yandan bireylerin iş bulma kuyruğunda ön sıralarda yer bulmasını sağlarken, diğer yandan bu bireylerle eşleşen işlerin yeterli sayıda olmaması nedeniyle aşırı eğitimlilik olgusunun ortaya çıkmasına neden olabileceği şeklinde yorumlanabilmektedir. Seçim denkleminde söz konusu değişkenin katsayısı pozitif ve istatistiki olarak anlamlıdır. Eğitim düzeyi arttıkça bireylerin istihdamda olma olasılığ artmaktadır. Bu sonuç “Beşerî Sermaye Teorisi’ni (Becker, 1964) desteklemektedir.

Kadınların erkeklere göre aşırı eğitimli olma olasılığı Tablo 8 ile verilen model sonuçlarına göre \%3, Tablo 9 ile verilen model sonuçlarına göre $\% 6$ daha azdır. Bu sonuç hanehalkı rollerindeki cinsiyet farklılıklarıyla ilişkilendirilebilmektedir. Toplumun pek çok kesiminde haneden sorumlu olma kavramı erkeğe atfedilmektedir. TÜİK Gelir ve Yaşam Koşulları Anketi, 2015 verilerine göre yaklaşık 21,9 milyon hane sorumlusunun \%18,2'si 
kadındır (Uysal \& Köksal, 2017: 1). Erkek, hanehalkının yönetimi ve geçiminden sorumlu olması nedeniyle çoğu zaman aldığı eğitimden daha düşük eğitim seviyesi gerektiren bir işte çalışmaya razı olmaktadır. $\mathrm{Bu}$ durum, eğitim-iş uyuşmazlığı sorununu meydana getirmektedir. Türkiye'de aşırı eğitim olgusunu inceleyen başka bir çalışmada benzer bulgulara rastlanmıştır; Filiztekin (2015); çalışmasında kadınların aşırı eğitimli olma olasılığının daha düşük olduğu sonucuna ulaşmıştır. Tablo 9 seçim denklemine bakıldığında evli kadın etkileşim teriminin, SGK'ya kayıtlı istihdamda olma olasılığının daha az olduğu görülmektedir. Evlilerin bekârlara göre SGK'ya kayıtlı istihdamda olma olasılığı ise daha fazladır. Ermini vd. (2017), çalışmasında benzer olarak evlilerin istihdamda olma olasılığının daha fazla, evli kadınların istihdamda olma olasılığının ise daha az olduğu sonucunu elde etmiştir.

Bireylerin işteki durumuna ait marjinal etkiler incelendiğinde Tablo 8 ve Tablo 9 ile verilen her iki modelde işverene göre, ücretli çalışanların ve kendi hesabına çalışanların aşırı eğitimli olma olasılığının daha fazla olduğu görülmektedir. Söz konusu artış Tablo 9 ile verilen modelde ücretli çalışanda $\% 5$ ve kendi hesabına çalışanda $\% 9$ olarak gerçekleşmiştir. Ücretsiz aile işçisine ilişkin katsayı Tablo 8 ile verilen modelde istatistiki olarak anlamlı ve negatif elde edilmiştir. Söz konusu değişkene ait katsayı Tablo 9 ile verilen model de ise istatistiki olarak anlamlı ve pozitiftir.

İşyeri statüsü değerlendirildiğinde özel sektör çalışanlarının kamu sektörü çalışanlarına göre aşırı eğitimli olma olasılığı Tablo 8'e göre \%3, Tablo 9'a göre \%6 daha fazladır. Dereli (2017), Türkiye işgücü piyasasında aşırı eğitimin nedenlerini incelediği çalışmasında, işyeri statüsünün, lise mezunlarının aşırı eğitimli olma olasılığı üzerinde etkisi olmadığ 1 ve yükseköğrenim mezunlarından kamu sektöründe çalışanların özel sektör çalışanlarına göre aşırı eğitimli olma olasılığının daha az olduğu sonucuna ulaşmıştır.

20-49 kişinin çalıştığı bir işyerine göre 50 veya daha fazla çalışanın olduğu işyerinde aşırı eğitimli olma olasılığının Tablo 8'de \%1, Tablo 9'da \%2 daha fazla olduğu görülmektedir. Büyük firmalar daha yüksek ücret düzeyine ve daha iyi kariyer olanaklarına sahiptir. Söz konusu firmalarda çalışanların terfi etme olasılığı daha yüksektir (HerreraIdárraga vd., 2012: 18). Bununla birlikte, çalışanlara özel sağlık ve hayat sigortası, yolyemek ücreti, şirket hattı, şirket arabası vb. yan haklar sağlanmaktadır. Büyük firmalardan gelen iş teklifleri iş arayanlar için cezbedicidir ve bu tür bir firmada kişi aldığı eğitimden daha düşük bir eğitim seviyesi gerektiren işe başvurmayı tercih edebilecektir.

Bölge sınıflamasına ilişkin katsayılara bakıldığında Tablo 8 ve Tablo 9 ile verilen her iki modelde istatistiksel olarak anlamlı sonuçlar elde edildiği görülmektedir. Tablo 8 ile verilen modelde aşırı eğitimli olma olasılığı Güneydoğu Anadolu bölgesine göre Orta Anadolu Bölgesinde \%2 fazla iken, İstanbul Bölgesinde \%0,6 azdır. Tablo 9 ile verilen modelde ise aşırı eğitimli olma olasılığı Güneydoğu Anadolu bölgesine göre Kuzeydoğu Anadolu Bölgesi ve Doğu Karadeniz Bölgesinde \%3 fazla iken, İstanbul Bölgesinde \%3 azdir. 
Tablo 8 ve Tablo 9 ile verilen her iki modelde inşaat sektörüne göre tarım, imalat ve maden sektörüne ilişkin katsayılar istatistiki olarak anlamlı ve pozitif, hizmetler sektörü katsayısı ise istatistiki olarak anlamlı ve negatif olarak elde edilmiştir. Söz konusu değişkenlerin Tablo 9 ile verilen modelde marjinal etkileri değerlendirildiğinde aşırı eğitimli olma olasılığının inşaat sektörüne göre tarım sektöründe $\% 14$, imalat sektöründe $\% 3$ ve maden sektöründe \%4 artacağı görülmektedir. Hizmetler sektöründe ise inşaat sektörüne göre aşırı eğitimli olma olasılı̆̆ $1 \% 1.1$ azalmaktadır. Hizmetler sektöründe işgücü devir hızı yüksektir. Eğitimli bireyler niteliklerine uygun bir iş buluncaya kadar geçici bir şekilde bu sektörde çalışabilmektedir (Emeç vd., 2019: 1627). Dolayısıyla eğitim iş uyuşmazlığı beklentisi diğer sektörlere kıyasla kısa sürelidir. Bu nedenler hizmetler sektörünün aşırı eğitimli olma olasılığı üzerinde negatif etkiye sahip olmasını açıklamaktadır.

Tablo 8 incelendiğinde 2017 yılına göre 2018 yılında aşırı eğitimli olma olasılığının azaldığı görülmektedir. Son yıllarda ekonomik büyümeyi sağlamaya yönelik çalışmalarda istihdamın niteliğinin arttırılması odak noktası haline gelmiştir. Bu yönde atılan adımların bireyleri kendileriyle eşleşen işler söz konusu olduğunda istihdama katılmaya yönlendirdiği ve bu durumun aşırı eğitimliliğin ortaya çıkışını azalttığı düşünülebilir. Tablo 9 seçim denkleminde 2017 yılına göre 2018 yılında SGK'ya kayıtlı istihdamda olma olasılığının \%0.2 azaldığı sonucuna ulaşılmıştır. Söz konusu dönemde dolar kurundaki ani yükselişle ortaya çıkan kur şokunun istihdamı ters yönde etkilediği söylenebilmektedir. Türk Lirasında yaşanan yüksek frekanslı değer kaybı talebin daralmasına ve işsizlik oranlarının artmasına neden olmuştur.

\section{Tartışma ve Sonuç}

Çalışmada Türkiye'de 2014-2018 yıllarında 15-65 yaş arası SGK’ya kayıtlı istihdamda olan bireylerin aşırı eğitimlilik durumları incelenmiş ve işgücü piyasası koşullarında bu ilişkinin nasıl çalıştığına ilişkin bir çerçeve sunulmuştur. Aşırı eğitimin belirleyicilerinden daha çok bireyin iş deneyimi ve eğitim düzeyinin aşırı eğitim üzerindeki etkisi üzerinde durulmuştur. Elde edilen bulgulara göre bireyin yaşı ve iş tecrübesi arttıkça aşırı eğitimli olma olasılığı azalmaktadır. "Kariyer Hareketliliği Teorisi" (Sicherman \& Galor 1990) varsayımı dâhilinde elde edilen bu bulgu hipotezimizi desteklemektedir. Bir diğer varsayım eğitim ile ilgilidir. Türkiye'de eğitim ve istihdam ilişkinin zayıf olması nedeniyle işgücü piyasasında emek arzı ve talebi arasında uyum sorunu ortaya çıkmaktadır. $\mathrm{Bu}$ noktada işgücünün eğitim düzeyinin ve kalitesinin arttırılması önemlidir. Çalışmada bireyin eğitim düzeyi arttıkça aşırı eğitimli olma olasılığının arttığı sonucuna ulaşılmıştır. Elde edilen bu bulgu "İş rekabeti teorisi (Thurow,1974)" ni desteklemektedir. Seçim denkleminde söz konusu değişkenin katsayısı "Beşerî Sermaye Teorisi” (Becker,1964) varsayımlarıyla tutarlı ve pozitif elde edilmiştir. Eğitim düzeyi arttıkça bireylerin istihdamda olma olasılığı artmaktadır. Ancak bireylerin eğitim düzeylerinin arttırılması, bu bireylerin istihdam edilebileceği yeni iş alanları yaratılmadığı sürece uyum sorunun çözümlenmesinde tek başına yeterli olmayacaktır. Bununla birlikte mesleki eğitim planlamaları piyasa talebini karşılamaya yönelik oluşturulmalıdır. Toplum işgücü piyasaları hakkında bilgilendirilmeli ve mevcut boş pozisyonlarla iş arayanlar arasında bir köprü oluşturan İŞKUR ve özel istihdam büroları gibi gerek kamuda gerekse de özel sektörde mesleki danışmanlık hizmeti 
veren kurumların faaliyetleri artırılmalıdır. Özetle aşırı eğitim olgusu sosyal politika açısından önemli bir ekonomik göstergedir. Aşırı eğitim, emeğin verimliliğini düşürmesi yoluyla ülke ekonomisini olumsuz etkilemektedir. Nitelikleriyle uyuşmayan işlerde çalışan bireyleri psikolojik açıdan etkileyerek yaşam kalitelerinin düşmesine neden olmaktadır. Dolayısıyla aşırı eğitimliliğin ortaya çıkmasında etkili olan faktörlerin belirlenip bu konularda tedbirlerin alınması önemlidir. Çalışmamız hanehalkı işgücü anketi ham verilerinden yola çıkarak gerçekleştirildiği için eksiklikleri de mevcuttur. Örneğin eş ve veya hanede yaşayan diğer bireylerin geliri, çocuk sayısı, haneden sorumlu kişi gibi değişkenlerin aşırı eğitimlilik üzerindeki etkisi ölçülememiştir. Ancak Türkiye'deki aşırı eğitimin ölçümü ile ilgili literatür incelendiğinde ortalama ile mod ölçümleri yapılmıştır. Çalışmamızda mevcut literatürde farklı görüşlerin olduğu tüm istatistiksel yöntemler bir arada irdelenmiştir. Bundan sonraki çalışmalarda Türkiye'de bölgelerde sektör bazlı aşırı eğitimliliğin ayrıca incelenmesi düşünülmektedir.

\section{Kaynaklar}

Acar, E.Ö. (2017), "The Effect of Education-Job Mismatch on Wages: A Panel Analysis of The Turkish Labor Market", International Journal of Economic \& Administrative Studies, (18), 339-354.

Bauer, T.K. (2002), "Educational Mismatch and Wages: A Panel Analysis", Economics of Education Review, 21(3), 221-229.

Becker, G. (1964), Human Capital: A Theoretical and Empirical Analysis with Special Reference to Education, New York: Columbia University Press.

Becker, G. (1991), A Treatise On the Family, Harvard University Press Cambridge, Massachusetts London, England.

Bonnal, M. \& L. Cristina \& N.A. Samuel (2009), "Underemployment and Local Employment Dynamics: New Evidence", The Review of Regional Studies, 39(3), 317-335.

Büchel, F. \& M. Van Ham (2003), "Overeducation, Regional Labour Markets, and Spatial Flexibility", Journal of Urban Economics, 53, 482-493.

Büchel, F. (2002), “The Effects of Overeducation on Productivity in Germany - The Firms' Viewpoint", Economics of Education Review, 21(3), 263-275.

Capsada-Munsech, Q. (2019), "Measuring Overeducation: Incidence, Correlation and Overlaps Across Indicators and Countries", Social Indicators Research, 145(1), 279-301.

Carnoy, M. (1989), "Eğitim ve Ekonomi İlişkisi”, Ankara Üniversitesi Eğitim Bilimleri Fakültesi Dergisi, Çev: N. Kurul 22(1), 485-504.

Chevalier, A. (2003), "Measuring Over-Education", Economica, 70(279), 509-531.

Çakmak, E. \& S. Gümüş (2005), "Türkiye'de Beşeri Sermaye ve Ekonomik Büyüme: Ekonometrik Bir Analiz”, Ankara Üniversitesi SBF Dergisi, 60(01), 59-72.

De Grip, A. \& H. Bosma \& D. Willems \& M. Van Boxtel (2008), "Job-Worker Mismatch and Cognitive Decline", Oxford Economic Papers, 60(2), 237-253.

De Oliveira, M.M. \& M.C. Santos \& B.F. Kiker (2000), "The Role of Human Capital and Technological Change in Overeducation", Economics of Education Review, 19(2), 199206. 
Dereli, B.E. (2017), "Determinants of Education Mismatch in Turkey: Evidence from Household Labor Force Surveys", Marmara Üniversitesi İktisadi ve İdari Bilimler Dergisi, 39(2), 521-532.

Dolton, P. \& A. Vignoles (2000), "The Incidence and Effects of Overeducation in The UK Graduate Labour Market", Economics of Education Review, 19, 179-198.

Duncan, G.J. \& S.D. Hoffman (1981), "The Incidence and Wage Effects of Overeducation", Economics of Education Review, 1(1), 75-86.

Emeç, H. \& Ş. Üçdoğruk-Birecikli \& B. Kümbül-Güler (2019), “Türkiye'de Gençlerde Eksik İstihdamın Analizi”, Business and Organization Research (International Conference), IZMIR, ISBN:978-605-68816-4-0.

Ermini, B. \& L. Papi \& F. Scaturro (2017) “An Analysis of the Determinants of Over-Education Among Italian Ph.D Graduates", Italian Economic Journal, 3, 167-207.

Filiztekin, A. (2015), “Türkiye Emek Piyasasında Eğitim-İş Uyuşmazlığı”, N. Yıldırım, Tuncer Bulutay'a Armağan, Mülkiyeliler Birliği Yayını, Ankara.

Freeman, R. (1976), The Overeducated American, Academic Press.

Gönültaş-Çelik, M. (2019), "İşü̈cü Piyasasının Bir Sorun Alanı Olarak Uyumsuz Eşleşme”, Yönetim ve Çalışma Dergisi, 3(2), 223-241.

Green, F. \& Y. Zhu (2010), "Overqualification, Job Dissatisfaction and Increasing Dispersion in The Returns to Graduate Education", Oxford Economic Papers, 62(4), 740-763.

Hartog, J. \& H. Oosterbeek (1988), "Education, Allocation and Earnings in The Netherlands: Overschooling?", Economics of Education Review, 7(2), 185-194.

Hartog, J. (2000), “Over-Education and Earnings: Where Are We, Where Should We Go?”, Economics of Education Review, 19(2), 131-147.

Heckman, J.J. (1979), "Sample Selection Bias as a Specification Error”, Econometrica, 47(1), 153161

Herrera-Idárraga, P. \& E. López-Bazo \& E. Motellón (2012), Informality and overeducation in the labor market of a developing country, XREAP2012-20.

Hersch, J. (1991), "Education Match and Job Match", The Review of Economics and Statistics, 73(1), $140-144$.

Hung, C.Y. (2008), "Overeducation and Undereducation in Taiwan", Journal of Asian Economics, $19(2), 125-137$.

ILO (2018), Measurement of qualifications and Skills Mismatches of Persons in Employment, <https://www.ilo.org/wcmsp5/groups/public/---dgreports/ stat/documents/meetingdocument/wcms_636052.pdf>, 17.05.2020.

ISCED (1997), The International Standard Classification of Education (ISCED) $<$ http://uis.unesco.org/sites/default/files/documents/international-standard-classificationof-education-1997-en_0.pdf>, 17.05.2020.

Kiker, B.F. \& M.C. Santos \& M.M. De Oliveira (1997), "Overeducation and Undereducation: Evidence for Portugal”, Economics of Education Review, 16(2), 111-125.

Kurnaz, I. (2014), “Bir Kariyer Stratejisi Olarak Aşırı Eğitimlilik Sıçrama Tahtası mı? Tuzak mı?”, Presented at the II. Uluslararası İs ve Meslek Danışmanlığ Kongresi.

Kurnaz, I. (2014), “İşgücü Piyasasında Uyumsuz Eşleşme ve Aşırı Eğitimlilik Olgusu: Geçici Bir Durum Mu-Kalıcı Bir Sorun Mu?", Seminer Çalışması, TOBB ETÜ Sosyal Politikalar Uygulama ve Araştırma Merkezi. 
Kantarmacı, S. \& S. Demirogları \& H. Erk \& Ş. Üçdoğruk-Birecikli (2021), "Türkiye İşgücü Piyasasında Bireylerin Aşırı Eğitimliliğinin Ölçülmesi: İki Değişkenli Probit Model Uygulaması”, Sosyoekonomi, 29(48), 271-292.

Kurnaz, I. (2015), “İşü̈ü Piyasasında Nitelik Uyumsuzluğu: Düşük Nitelikli İşlerde Yüksek Nitelikli İşgücü”, Siyaset, Ekonomi ve Yönetim Araştırmaları Dergisi, 16. Çalışma Ekonomisi ve Endüstri İlişkileri Kongresi Özel Sayısı, 83-121.

Kurnaz, I. (2015), Ekonomik Kriz Dönemlerinde Hangisi Daha Kötü: Işsisiz Kalmak mı? Niteliklerinin Altındaki İsleri Kabul Etmek mi?, <http://www.dergikaratahta.com/files/1/3.pdf>,11.03.2020.

Lin, C. \& C. Wang (2005), "The Incidence and Wage Effects of Overeducation: The Case of Taiwan", Journal of Economic Development, 30(1), 31-47.

McGuinness, S. (2006), "Overeducation in The Labour Market”, Journal of Economic Surveys, 20(3), 387-418.

Nieto, S. (2014), "Overeducation, Skills and Wage Penalty: Evidence for Spain Using PIAAC Data", AQR-Working Papers, AQR14/06.

OECD (2019), "Skills Matter: Additional Results from the Survey of Adult Skills", OECD Skills Studies, OECD Publishing, Paris.

Ortiz, L. \& A. Kucel (2008), "Do Fields of Study Matter for Over-Education? The Cases of Spain and Germany", International Journal of Comparative Sociology, 49(4-5), 305-27.

Ramos, M. (2014), "Mismatched Mismatch Measures. Does The Definition of Over-and UnderQualification Matter?", In XVII Applied Economics Meeting, Gran Canaria (5-6).

Rossen, A. \& C. Boll \& A. Wolf (2019), "Patterns of Overeducation in Europe: The Role of Field of Study", IZA Journal of Labor Policy, 9(1).

Saxton, J. (2000), "Investment in Education: Private and Public Returns", U.S Congress Joint Economic Committee, Washington DC.

Sicherman, N. \& O. Galor (1990), “A Theory of Career Mobility”, Journal of Political Economy, 98, 169-192.

StataCorp. (2007), Stata Statistical Software, Release 10, College Station, TX.

Thurow, L.C. (1974), "Measuring the Economic Benefits of Education”, M. Gordon, Higher

Education and the Labor Market, New York: McGraw-Hill, 373-418.

TÜíK (2019), Eğitim Harcamaları, 2018,

<http://www.tuik.gov.tr/PreHaberBultenleri.do?id=30588>, 18.12.2019.

TÜİK (2019), Issgücü İstatistikleri, 2018, <http://www.tuik.gov.tr/PreHaberBultenleri.do?id=33784>, 20.03.2020.

TÜİK (2020), İsgücü İstatistikleri, <https://biruni.tuik.gov.tr/medas/?kn=72\&locale=tr>, 19.04.2020.

Uysal, G. \& S. Köksal (2017), "Reisi Kadın Olan Hanelerde Yoksunluk Artıyor”, Bahçeşehir Üniversitesi Araştırma Notu, 17/206.

Ünal, L.I. (1996), Eğitim ve Yetistirme Ekonomisi, Ankara: Torun Matbaası.

Van de Ven, W.P.M.M. \& B.M.S. van Pragg (1981), "The Demand for Deductibles in Private Health Insurance: A Probit Model with Sample Selection”, Journal of Econometrics, 17, 229252.

Van Smoorenburg, M.S. \& R.K. Van der Velden (2000), “The Training of School-Leavers: Complementarity or Substitution?", Economics of Education Review, 19(2), 207-217.

Verdugo, R.R. \& N.T. Verdugo (1989), "The Impact of Surplus Schooling on Earnings: Some Additional Findings", Journal of Human Resources, 24(4), 629-643. 
Verhaest, D. \& E. Omey (2006), "The Impact of Overeducation and Its Measurement", Social Indicators Research, 77(3), 419-448.

Verhaest, D. \& E. Omey (2009), "Objective Over-Education and Worker Well-Being: A Shadow Price Approach”, Journal of Economic Psychology, 30(3), 469-481.

YÖK (2020), Yükseköğretim Bilgi Yönetim Sistemi, <https://istatistik.yok.gov.tr/>, 17.05.2020. 